\title{
Hold-up and the Use of Performance-sensitive Debt
}

\author{
Adam, Tim R.; Streitz, Daniel
}

Document Version

Accepted author manuscript

Published in:

Journal of Financial Intermediation

DOI:

10.1016/j.jfi.2016.01.004

Publication date:

2016

License

CC BY-NC-ND

Citation for published version (APA):

Adam, T. R., \& Streitz, D. (2016). Hold-up and the Use of Performance-sensitive Debt. Journal of Financial Intermediation, 26, 47-67. https://doi.org/10.1016/j.jfi.2016.01.004

Link to publication in CBS Research Portal

\section{General rights}

Copyright and moral rights for the publications made accessible in the public portal are retained by the authors and/or other copyright owners and it is a condition of accessing publications that users recognise and abide by the legal requirements associated with these rights.

Take down policy

If you believe that this document breaches copyright please contact us (research.lib@cbs.dk) providing details, and we will remove access to the work immediately and investigate your claim. 


\section{Hold-up and the Use of Performance-sensitive Debt Tim R. Adam and Daniel Streitz}

Journal article (Accepted manuscript*)

\section{Please cite this article as:}

Adam, T. R., \& Streitz, D. (2016). Hold-up and the Use of Performance-sensitive Debt. Journal of Financial Intermediation, 26, 47-67. https://doi.org/10.1016/j.jfi.2016.01.004

Dol: https://doi.org/10.1016/j.jfi.2016.01.004

* This version of the article has been accepted for publication and undergone full peer review but has not been through the copyediting, typesetting, pagination and proofreading process, which may lead to differences between this version and the publisher's final version AKA Version of Record.

Uploaded to CBS Research Portal: March २०२०

(C) २०२०. This manuscript version is made available under the CC-BY-NC-ND 4.0 license http://creativecommons.org/licenses/by-nc-nd/4.0/ 


\title{
Hold-Up and the
}

\section{Use of Performance-Sensitive Debt}

\author{
Tim R. Adam and Daniel Streitz*
}

\begin{abstract}
We examine whether performance-sensitive debt (PSD) is used to reduce hold-up problems in long-term lending relationships. We find that the use of PSD is more common in the presence of a long-term lending relationship and if the borrower has fewer financing alternatives available. In syndicated deals, however, the presence of a relationship lead arranger reduces the use of PSD because a lead arranger has little incentive to hold-up a client. Further supporting the hypothesis that hold-up concerns motivate the use of PSD, we find a substitution effect between the use of PSD and the tightness of financial covenants.
\end{abstract}

Keywords: Performance-sensitive debt, relationship lending, hold-up, holdout, syndicated

debt, covenants

JEL-Classification: G21, G31, G32

*Tim R. Adam is at the Institute of Corporate Finance, Humboldt University Berlin. Daniel Streitz is at E.CA Economics Berlin. The authors wish to thank Sugato Bhattacharyya, Arnoud Boot, Darwin Choi, Hans Christensen, Georges Dionne, Ruediger Fahlenbrach, Felix Feng, Bjoern Imbierowicz, Gustavo Manso, Rafael Matta, Gordon Phillips, Michael Roberts, Joao Santos, Anthony Saunders, Alexander Schandlbauer, Larissa Schaefer, Mark Seasholes, Sascha Steffen, Ernst-Ludwig von Thadden, Hirofumi Uchida, and Zexi Wang as well as seminar participants at ESMT, HEC Montreal, HKUST, University of Mannheim, Nanyang Technological University, and National University of Singapore, and participants at 2013 CICF, 2013 FIRS, 2013 DGF, 2015 EFA, the Second Edinburgh Corporate Finance Conference, and the 2015 European Winter Finance Summit for helpful comments and suggestions. The authors would also like to thank Paolo Bizzozero for excellent research assistance. The authors gratefully acknowledge support from the Deutsche Forschungsgemeinschaft through the Collaborative Research Centers SFB 649 "Economic Risk" and SFB/TR15 "Governance and the Efficiency of Economic Systems". Contact information: Tim Adam, Tel.: +49(0)30 2093 5641, e-mail: tim.adam@hu-berlin.de; Daniel Streitz, Tel.: +49(0)30 21231 7091, e-mail: streitz@e-ca.com. 


\title{
Hold-Up and the
}

\section{Use of Performance-Sensitive Debt}

\begin{abstract}
We examine whether performance-sensitive debt (PSD) is used to reduce hold-up problems in long-term lending relationships. We find that the use of PSD is more common in the presence of a long-term lending relationship and if the borrower has fewer financing alternatives available. In syndicated deals, however, the presence of a relationship lead arranger reduces the use of PSD because a lead arranger has little incentive to hold-up a client. Further supporting the hypothesis that hold-up concerns motivate the use of PSD, we find a substitution effect between the use of PSD and the tightness of financial covenants.
\end{abstract}

Keywords: Performance-sensitive debt, relationship lending, hold-up, holdout, syndicated debt, covenants

JEL-Classification: G21, G31, G32 


\section{Introduction}

Since the early 1990s, many bank loans contain performance pricing provisions, which stipulate that the coupon paid rises if the firm's financial performance deteriorates and/or vice versa. Financial performance is measured either by the borrower's credit rating or a financial ratio such as leverage. The theoretical literature has linked the use of performance-sensitive debt (PSD) to debt renegotiation costs, signaling, and asset substitution considerations. Asquith et al. (2005) argue that PSD reduces debt renegotiation costs due to adverse selection, moral hazard, or unanticipated changes in the borrower's credit risk. Manso et al. (2010) demonstrate that PSD can be used as a signaling device for a firm's credit quality in a setting with adverse selection. Finally, Koziol and Lawrenz (2010) show that PSD can mitigate risk-shifting incentives, but Bhanot and Mello (2006) argue that PSD is an inefficient method to reduce incentives for asset substitution.

In this paper we explore a new explanation for the use of PSD. We hypothesize that PSD can be used to mitigate hold-up problems, which, for example, can arise in long-term lending relationships. Sharpe (1990) and Rajan (1992) show that a cost of relationship lending is the potential for hold-up by the lender. The potential for hold-up arises from the information advantage, which the lender acquires in the course of the lending relationship. This information advantage makes it difficult for the borrower to switch to another, less well informed, lender due to adverse selection, which is especially relevant for opaque borrowers with fewer 
financing alternatives. If the borrower is "locked in", the bank could exploit the situation by charging higher interest rates or by denying interest rate reductions when the borrower's performance improves. Schmidt (2006) argues that the use of covenants, which is common in private debt contracts, further exacerbates the hold-up problem because covenants shift bargaining power from borrowers to lenders. Von Thadden (1995) shows that a solution to this hold-up problem is to pre-specify contract terms ex ante, thereby limiting the discretion of the lender. Indeed, one can view PSD contracts as limiting the discretion of the lender because the performance-pricing provision stipulates coupon adjustments if the borrower's performance changes, thereby avoiding debt renegotiations in these states. For example, rather than renegotiate a loan after a covenant violation, the performance-pricing provision specifies the outcome of such renegotiation ex ante and thus avoids the situation of a technical default. Consistent with this argument Nikolaev (2013) finds that debt renegotiations are less common if loan contracts contain performance-pricing provisions. ${ }^{1}$

Furthermore, we argue that in syndicated deals, the presence of a relationship leadarranger is likely to reduce the use of PSD. In the decision to hold-up a client a lender needs to weigh the short-term gains from hold-up against the long-term costs of jeopardizing the relationship. In a syndicated deal, the short-terms gains from hold-up would be shared by

1 While PSD is common place in private debt markets, it is rare in public bond markets. Using keyword searches on both Bloomberg and EDGAR Pro we are able to identify only 115 performance-sensitive bond issues from 74 distinct companies between 1989 and 2012. In contrast, there are over 12,000 private debt issues with performance-pricing provisions over the same period. The relative rarity of PSD in public debt markets is consistent with the hold-up hypothesis because hold-up problems are of less concern in public debt. 
all syndicate members, while the long-term costs of jeopardizing the relationship would be borne mostly by the relationship lender. Thus, a relationship lead-arranger is more likely to favor to continue the relationship and benefit from its information advantage relative to other lenders rather than to hold-up a client.

Our paper is the first to explicitly investigate a possible link between hold-up problems in repeated lending relationships and the use of PSD contracts. A particular advantage of focusing on lending relationships is that it allows us to differentiate the hold-up hypothesis from the signaling motivation. This is because signaling is less important in lending relationships, as the relationship lender already has an information advantage (see for example Menkhoff et al. (2006)), while the potential for hold-up rises in lending relationships. Using a large sample of private debt contracts issued by non-financial U.S. borrowers between 1993 and 2011, we show that accounting-based PSD contracts, i.e., PSD based on a financial ratio, are about $25 \%$ more likely to be used in repeated lending relationships after we control for the endogeneity of the lending relationship. Next, we analyze whether the use of PSD varies systematically across different types of borrowers because the potential for hold-up is also a function of borrower characteristics. For example, Santos and Winton (2008) argue that the costs of relationship lending are higher for companies, which do not have access to other financing sources (e.g., bond market access). In line with this argument, we find that accounting-based PSD contracts are more common in relationship lending arrangements with smaller firms, firms that do not have a long-term issuer credit rating at the time of the 
loan origination, and firms with lower analyst coverage. If a loan is syndicated, performance pricing provisions are more likely, which is consistent with the renegotiation cost argument by Asquith et al. (2005). However, the presence of a lending relationship between the borrower and the lead arranger reduces the use of PSD. This is consistent with the argument that in a syndicate the lead arranger cannot capture all rents from hold-up, causing hold-up to be a less attractive strategy for the lead arranger than preserving the relationship with the client.

We further examine the structure of covenants in PSD because if performance pricing provisions are used to mitigate hold-up problems, then there should be a substitution effect between the pricing grid of rate-increasing $\mathrm{PSD}^{2}$ and covenant tightness. Covenants should be less tight compared to covenants of regular debt. ${ }^{3}$ This is what we find. Firstly, the majority of PSD have covenants on the same performance measure as the one used in the performance-pricing provision, with covenant thresholds typically set directly at the end of the pricing grid. Secondly, Debt-to-EBITDA covenants, the most common covenant type in our loan sample, are less tight in PSD contracts that also use Debt-to-EBITDA as a measure of the borrower's performance compared with non-PSD debt contracts. Consistent with the substitution hypothesis, this effect exists only for interest-increasing PSD contracts.

In contrast to accounting-based PSD we find no evidence of hold-up considerations in

2 PSD that allows for interest rate increases only.

3 Small deteriorations in a borrower's performance, which would otherwise trigger a technical default now automatically lead to interest rate increases as determined by the pricing grid. 
the use of rating-based PSD, i.e., PSD based on the borrower's credit rating. If anything, rating-based PSD is less likely used in long-term lending relationships. Since signaling considerations are less important in the presence of lending relationships it is possible that rating-based PSD is mostly used for signaling reasons, as proposed by Manso et al. (2010). To differentiate hold-up from the possibility that PSD is used to signal credit quality, we examine the evolution of the borrower's credit rating and the borrower's leverage ratio up to 2 years following the issue of PSD. Under the signaling hypothesis, firm's performance should improve following a PSD issue, while the hold-up hypothesis makes no prediction about the firm's post-issue performance. We find that borrowers' credit ratings tend to improve and leverage ratios decline 1-2 years following the issue of rating-based PSD, but not for accounting-based PSD. Thus, these results suggest that accounting-based PSD is used to address hold-up problems in repeated lending relationships, while rating-based PSD is more likely used to signal credit quality.

We make two main contributions to the literature. Firstly, we offer a new explanation for the use of PSD, namely that PSD reduces potential hold-up problems in repeated lending relationships. In contrast, Manso et al. (2010) argue that borrowers use PSD to signal their credit quality, while Koziol and Lawrenz (2010) argue that PSD reduces moral hazard. The study that is closest to our own is Asquith et al. (2005), who argue that the use of PSD reduces debt renegotiation costs. In contrast to renegotiation costs, however, hold-up does not arise in all situations and implies a wealth transfer between borrower and lender. 
Secondly, we add to the literature on hold-up in repeated lending relationships. Several authors find evidence that is consistent with the presence of hold-up. Saunders and Steffen (2011) find that private firms pay higher loan spreads than public firms if borrowing from a relationship bank. Hale and Santos (2009) show that banks reduce the interest rates on loans after a client successfully issued its first public bond. Santos and Winton (2008) find that (all else equal) loan spreads of bank-dependent borrowers rise more during recessions than loan spreads of borrowers who have access to public debt markets. Mattes et al. (2012) find that capital-constrained (European) banks charge borrowers with high switching costs higher loan spreads than well-capitalized banks. This effect prevails only during recessions. Degryse and Cayseele (2000) find evidence for a deterioration of contract terms over the duration of the lending relationship for a sample of European firms. ${ }^{4}$ Boot (2000) argues that maintaining multiple bank relationships can be one potential solution for this problem. ${ }^{5}$

However, Ongena and Smith (2000) show that this may reduce the availability of credit, because increased competition reduces the value of information acquisition and hence the

4 There is also considerable evidence of the benefits of lending relationships. Petersen and Rajan (1994) find that the duration of a bank-firm relationship does not influence the contracted loan rate, but Berger and Udell (1995) document that rates on lines of credit and collateral requirements decrease with the duration of the bank-firm relationship. Bharath et al. (2011) find that repeated borrowing from the same lender translates into a 10-17 bps lowering of loan spreads, and that relationships are especially valuable when borrower transparency is low. See Boot and Thakor (2000), Elsas and Krahnen (1998), Freudenberg et al. (2014), Berlin and Mester (1998), Bharath et al. (2007), Bharath et al. (2011), and Schenone (2010) for further empirical evidence on the benefits of lending relationships.

5 Houston and James (1996) find that firms with a single bank relationship use less bank debt, as growth opportunities are higher. Farinha and Santos (2002) find that firms with higher growth opportunities or greater bank dependence are more likely to switch to multiple bank relationships. All of the abovementioned evidence is consistent with the notion that multiple bank relationships reduce hold-up problems. 
incentive to lend to "young" firms. ${ }^{6}$ We extend this literature by linking the use of PSD to the hold-up problem in repeated lending relationships.

The remainder of the paper proceeds as follows. Section 2 presents our hypotheses. Section 3 describes the sample selection process, outlines the construction of variables, and presents some descriptive findings. Section 4 contains the main empirical analysis, which demonstrates a link between relationship lending and the use of performance pricing provisions. Section 5 explores alternative explanations, and Section 6 concludes.

\section{Hypothesis development}

Sharpe (1990) and Rajan (1992) show that a long-term lending relationship creates an information asymmetry between the relationship lender and other potential lenders, which can be costly for the borrower. Adverse selection can make it difficult for the borrower to switch to another lender. In this case the relationship lender could take advantage of its information monopoly and extract some rents from the borrower, especially in the event of covenant violations, when much bargaining power rests with the lender (see Chava and Roberts (2008)). Von Thadden (1995) argues that one way of reducing this hold-up problem is to limit the discretion of the lender by using pre-specified contract terms. PSD can be interpreted as

6 The availability of funds to young firms without a track record is one potential benefit of relationship lending as shown by Petersen and Rajan (1995). Banks can "subsidize" borrowers in earlier periods in return for higher rents in future periods when the banks have an information monopoly. 
such a pre-specification of contract terms. PSD contracts specify higher (lower) interest payments if the borrower's performance deteriorates (improves) in the future. A performance deterioration could trigger a covenant violation, which would subject the borrower to holdup. In the case of PSD, however, there would be no technical default situation since interest rate increases have been negotiated ex ante in the case of performance deteriorations. Similarly, a performance improvement could cause the borrower to request improved loan terms. A relationship lender may hold-up the borrower and deny any changes to the loan terms knowing that the borrower is locked in the relationship. In the case of PSD, however, there would be an automatic adjustment to the loan terms if the borrower's performance changes. Thus, a PSD contract limits the discretion of the lender and therefore can reduce hold-up in long-term lending relationships. ${ }^{7}$ This gives rise to our first hypothesis:

Hypothesis 1a Relationship loans are more likely to include performance-pricing provisions than non-relationship loans.

In contrast, Manso et al. (2010) argue that PSD is used to signal a firm's credit quality. Relationship lending provides an excellent setting to disentangle the two hypotheses because hold-up is more likely in repeated relationship lending, while the need for signaling is less likely. There is little need to signal if the lender possesses an information advantage already (see Menkhoff et al. (2006)). Thus, if the use for PSD is motivated by signaling

\footnotetext{
7 A performance pricing provision can also be valuable for a lender who is trying to attract high quality borrowers because PSD is a commitment device not to expropriate the borrower ex post.
} 
considerations, we expect a negative relation between relationship lending and the use of PSD.

Hypothesis $\mathbf{1 b}$ Relationship loans are less likely to include performance-pricing provisions than non-relationship loans.

Santos and Winton (2008) argue that the severity of the hold-up problem can vary systematically across different types of borrowers. For example, the degree to which a borrower is "locked-in" in a lending relationship depends on the availability of other financing sources, such as public bond market access, and the opaqueness of the borrower. This gives rise to our second hypothesis:

Hypothesis 2 Firms with fewer outside financing alternatives, which borrow from a relationship lender are more likely to use performance-sensitive debt.

When renegotiating a loan, a relationship lender must weigh the short-term benefits of holding-up the borrower against the long-term benefits of maintaining the relationship. In syndicated deals the lead arranger must share the benefits of hold-up with the rest of the syndicate, while the benefits of the relationship accrue mostly to the relationship lender. Therefore, a relationship lead arranger in a syndicate should be less likely to hold-up a borrower, so that the use of performance-pricing provisions should be less likely compared to non-relationship loans. We therefore expect that

Hypothesis 3 Syndicated relationship loans are less likely to include performance-pricing 
provisions than syndicated non-relationship loans.

Covenants especially present an opportunity for hold-up, because after covenant violations, lenders have much bargaining power vis-a-vis their borrowers. The most common consequence of covenant violations is that the coupon the borrower has to pay is revised upward. To eliminate hold-up in these situations, the coupon increases could be pre-contracted using performance-pricing provisions. The threshold at which a covenant ultimately kicks in would then have to be set higher than in the absence of a performance-pricing provision. Thus, there is a substitution effect between the use of a pricing grid and the tightness of the respective covenant. Figure 1 illustrates this graphically.

[Figure 1 here]

We therefore test the following hypothesis.

Hypothesis 4 Interest-increasing performance-sensitive loans have less tight covenants on the same performance measure, which is also used in the pricing grid.

Manso et al. (2010) argue that PSD is used to signal a firm's credit quality. If so, a firm's credit quality should improve on average following the issuance of PSD. In contrast, the holdup hypothesis makes no prediction with respect to the borrower's post issue performance. We therefore test the following hypothesis. 
Hypothesis 5 The issuer's performance improves (does not improve) following the issue of $P S D$.

\section{Data description}

We obtain our loan sample from the Thomson Reuters Loan Pricing Corporation Dealscan (LPC's Dealscan) database, which contains detailed information on corporate loan issues.

We restrict our sample to loans issued by U.S. non-financial borrowers between 1993 and 2011. ${ }^{8}$ Consistent with the prior literature (e.g., Berg et al. (2015), Bharath et al. (2007)), we conduct our analysis on the facility (tranche) level. We obtain information on loan characteristics such as maturity, the loan amount (scaled by total assets), number of covenants, as well as the loan purpose and loan type. In addition, we record whether a loan is secured or not. We then merge our loan data with borrower-specific information obtained from Standard and Poor's Compustat North America database, such as firm size, market-to-book etc., from the last available fiscal quarter before the loan issue. ${ }^{9}$ The Appendix contains the definitions of all variables used in our analysis.

8 Prior to 1993, virtually no contracts include a performance-pricing provision according to Dealscan. As PSD clearly existed prior to 1993, we conclude that Dealscan's data quality with respect to PSD is insufficient prior to 1993.

9 We use Michael Robert's Dealscan-Compustat Linking Database to merge Dealscan with Compustat (see Chava and Roberts (2008)). 


\subsection{Performance-sensitive debt contracts}

The most common performance measure used in PSD contracts is the Debt-to-EBITDA ratio ( 48\% of all PSD loans issued by U.S. borrowers) followed by the issuer's senior debt rating $(\sim 26 \%)$. Dealscan also reports the exact pricing grid, i.e., the function, which links the coupon payments to the performance measure. Figure 2 shows the pricing grid of a loan issued by Urban Outfitters Inc. in September 2007. The spread paid by Urban Outfitters increases with its Debt-to-EBITDA ratio (an accounting-based PSD). Urban Outfitter's Debt-to-EBITDA ratio at the time of the issue was 4, implying that this loan is an example of a rate-decreasing contract. Figure 3 shows the pricing grid of a loan issued by IBM in March 2004. In this contract, the loan spread changes with IBM's senior debt rating (a rating-based PSD). Since IBM's senior debt rating at the time of the issue was A+, this loan is an example of a rate-increasing and rate-decreasing contract.

[Figures $2 \& 3$ here]

\subsection{Measuring relationship strength}

We follow Bharath et al. (2011) and construct three proxies for the strength of the lending relationship between borrower and lender. To construct these proxies, we first need to identify the lead lender(s) for each loan contract. As in Sufi (2007), we classify a lender 
as the lead lender if the variable "Lead Arranger Credit" (provided by LPC's Dealscan) takes on the value "Yes", or if the lender is the only lender specified in the loan contract. Next, we search the borrowing record of the borrower over the past five years. The first proxy for the strength of the lending relationship, Rel(Dummy), is a dummy variable, which equals one if the firm borrowed from the same lead lender in the previous five years and zero otherwise. ${ }^{10}$ If there are multiple lead lenders in a loan, we calculate the proxy separately for each lender and assign the highest value to the loan. The second proxy, Rel(Number), measures the relative number of loans obtained from the relationship lender. For bank $m$ lending to borrower $i$, it is calculated as follows.

$$
\operatorname{Rel}(\text { Number })_{m}=\frac{\text { Number of loans by bank } m \text { to borrower } i \text { in the last } 5 \text { years }}{\text { Total number of loans by borrower } i \text { in the last } 5 \text { years }}
$$

Again, the highest value is assigned to a loan if there are multiple lead lenders. The third proxy, $\operatorname{Rel}($ Amount), measures the relative loan amounts obtained from the relationship lender. For bank $m$ lending to borrower $i$, it is calculated as follows.

$$
\operatorname{Rel}(\text { Amount })_{m}=\frac{\text { Loan amount by bank } m \text { to borrower } i \text { in the last } 5 \text { years }(\$)}{\text { Total amount of loans by borrower } i \text { in the last } 5 \text { years }(\$)}
$$

\footnotetext{
${ }^{10}$ Dealscan often classifies borrowers at the subsidiary level, e.g., General Electric Capital Canada and General Electric Capital Corp of Puerto Rico are two distinct borrowers in Dealscan. By using the Michael Robert's Dealscan-Compustat Linking Database, all wholly-owned subsidiaries are effectively aggregated under the ultimate parent. We apply the same procedure to lenders. This procedure is important to ensure that, e.g., a switch from Lehman Brothers Inc [Frankfurt] to Lehman Brothers Asia is not classified as an actual lender switch. Not aggregating the borrowers and lenders under the ultimate parent, however, does not affect our results qualitatively.
} 
Again, the highest value is assigned to a loan if there are multiple lead lenders.

\subsection{Measuring the tightness of covenants}

As noted by Demiroglu and James (2010), covenant slack, i.e., the difference between the covenant threshold and the value of the covenant variable at the initiation of the loan agreement, is an intuitive measure of covenant tightness. However, the degree of tightness also depends on the volatility of the covenant variable and is thus firm-specific. We therefore follow Dichev and Skinner (2002) and define covenant tightness as the difference between the covenant variable at the initiation of the loan agreement and the covenant threshold, normalized by the standard deviation of the covenant variable over the previous 8 years. ${ }^{11}$ Since various definitions of leverage and liquidity ratios are used in practice, we restrict our analysis to covenants on the Debt-to-EBITDA ratio, which, as Dichev and Skinner (2002) note, has the most consistently used definition.

\footnotetext{
${ }^{11}$ According to Bradley and Roberts (2003), the tightness of covenants can also be measured by a covenant intensity index, which ranges from zero to six, with higher values indicating stricter covenants. The index is constructed by summing indicator variables on dividend restrictions, equity sweep, asset sweep, debt sweep, securitization and a binary variable that equals one if the contract includes two or more financial covenants. Murfin (2012) further considers covariation between the different covenant variables when measuring contract strictness. We do not use these indices because we are interested in the tightness of a particular covenant rather than general covenant tightness.
} 


\subsection{Descriptive statistics}

Table 1 presents descriptive statistics for our sample consisting of 25,900 loan tranches issued by 4,958 distinct borrowers between 1993 and 2011. Following Bharath et al. (2011), the data are winsorized at the $1 \%$ and $99 \%$ levels to remove outliers. Panel A reports loan characteristics, which are consistent with prior studies, e.g., Sufi (2007). For example, the mean/median tranche amounts in our sample are $\$ 314 / \$ 110$ million, which is large given the mean/median book value of assets of $\$ 3,287 / \$ 657$ million and an average leverage ratio of $29 \%$. The average all-in-drawn spread is 204 basis points, and the average maturity is 3.75 years. $74 \%$ of loan tranches are credit lines. Consistent with Manso et al. (2010), roughly $47 \%$ of loans include a performance-pricing provision. ${ }^{12}$

Panel B reports borrower characteristics. In $55 \%$ of cases, borrowers do not have a credit rating, but if a rating exists it tends to be around the investment grade threshold. Panel $\mathrm{C}$ reports descriptive statistics on the three relationship lending proxies. A lending relationship exists in $62 \%$ of all loan contracts. On average, $42 \%$ of the total capital raised over the course of 5 years was raised from the same lead lender.

[Table 1 here]

\footnotetext{
${ }^{12}$ Note that the number of observations is lower for the variables Increasing PSD, Mixed PSD, and Decreasing $P S D$. We set these variables to missing if the initial spread is outside of the pricing grid ( $<1 \%$ of cases).
} 
Table 2 shows the various performance measures used in PSD contracts. The most common performance measure is the Debt-to-EBITDA ratio (48\%), followed by the senior debt rating $(26 \%)$. The remaining performance measures are mostly other leverage ratios. In at least $4 \%$ of cases, multiple performance measures are used. We define PSD as accountingbased PSD whenever a financial ratio is used as a measure of firm performance. Rating-based PSD comprise all PSD contracts, which use the borrower's credit rating as a performance measure.

[Table 2 here]

\section{Results}

\subsection{Lending relationships and the use of performance-sensitive debt}

We begin by analyzing the interaction between lending relationships and the choice between PSD and straight debt. As noted in Section II, we distinguish between accounting-based and rating-based PSD. We therefore estimate a multinomial logistic regression.

$$
P S D_{i t}=\alpha+\alpha_{I n d}+\alpha_{t}+\alpha_{R a t}+\beta * \operatorname{Rel}(M)_{i t}+\gamma * X_{i t}+\epsilon_{i t}
$$

The dependent variable, $P S D$, is a discrete variable, which equals one if the loan contract 
contains a performance pricing provision on an accounting measure, two if the loan contract includes a performance pricing provision on the borrower's credit rating, and zero in the case of straight debt (control group). $\operatorname{Rel}(M)$ represents one of our three measures of relationship strength, and $X$ are control variables to control for heterogeneity in borrower and loan characteristics. We use firm size, measured by the log of total assets, the market-to-book ratio of assets, leverage, tangibility, profitability, the current ratio, the loan amount (scaled by total assets), the deal maturity, and an indicator variable for secured loans as control variables. We also include loan purpose and loan type indicators, time fixed effects, industry fixed effects, and dummy variables for each rating level. We cluster the standard errors at the firm level to account for non-independent observations within firms. Table 3 reports the regression results.

[Table 3 here]

We find that relationship strength is positively and significantly correlated with the use of accounting-based PSD. This is what we would expect if the possibility of hold-up in lending relationships motivates the use of PSD. ${ }^{13}$ In contrast, relationship strength appears to be weakly negatively related to the use of rating-based PSD. This result suggests that ratingbased PSD is unlikely used to address hold-up concerns. This conclusion is further supported

\footnotetext{
${ }^{13}$ When further distinguishing between interest-increasing, interest-decreasing, and mixed PSD, we find that all three types of accounting-based PSD are positively correlated with relationship strength. These results are available from the authors upon request.
} 
by the fact that there are virtually no covenants on a borrower's credit rating. This implies that hold-up due to covenant violations could not be addressed by rating-based PSD. Instead rating-based PSD may be used for signaling because there is less need for signaling in the presence of a lending relationship due to the information advantage of a relationship lender.

Consistent with the existing literature on PSD (e.g., Tchistyi et al. (2011)), larger loan amounts are more likely to include a performance-pricing provision. Loan maturity is positively correlated with the use of accounting-based PSD, which is consistent with Asquith et al. (2005)'s hypothesis that performance-pricing provisions are used in contracts with a higher renegotiation likelihood. Loan contracts are more likely to be renegotiated the longer the maturity. Larger borrowers are less likely to include an accounting-based performancepricing provision in the loan contract, possibly because large borrowers have more financing alternatives and therefore are less subject to hold-up. These initial results show that it is accounting-based PSD contracts, which may be motivated by hold-up due to lending relationships, while rating-based PSD are unlikely to be motivated by hold-up considerations. In the following analysis, we therefore exclude rating-based PSD and return to the issue of signaling in Section IV.

The analysis so far presents mostly cross-sectional evidence. However, our control variables may not fully capture all differences between relationship and non-relationship borrowers. If unobservable differences between borrower types are correlated with the use of PSD, 
our estimates are biased. We therefore include firm-fixed effects to control for unobservable time-invariant differences across firms, and analyze the use of PSD across loans within firms. The results of linear probability models relating the use of accounting-based PSD to measures of relationship strength are reported in Table $4 .{ }^{14}$

[Table 4 here]

Confirming our previous findings, relationship strength is positively and significantly correlated with the use of accounting-based PSD, even after controlling for time-invariant differences across firms. This implies that for the same firm the likelihood to use PSD increases if the firm borrows from the same lender for a second time within 5 years. This result is consistent with the prediction that the threat of hold-up increases over the course of a lending relationship. We include firm-fixed effects in all of our remaining analysis. However, all results remain qualitatively similar if we exclude firm-fixed effects and focus on the cross-sectional differences.

The decision to form and stay in a lending relationship is clearly an endogenous choice, which has been recognized in a number of recent studies, e.g. Agarwal and Hauswald (2010), Bharath et al. (2011), Coval and Moskowitz (2001), Dass and Massa (2011), Degryse and Ongena (2005), Norden and Weber (2010), and Petersen and Rajan (2002). We follow this

\footnotetext{
${ }^{14}$ We use linear probability models because of the large number of fixed effects. However, all results reported in this paper remain virtually unchanged if we use logit models.
} 
literature and use the geographic distance between the borrower and the lead lender as an instrument for relationship strength. This instrument is likely to be correlated with the decision to form a lending relationship but unlikely to be correlated with the decision to include a performance-pricing provision in the loan contract. Lenders that are physically closer to a borrower are more likely to have better information about a borrower, and are hence more likely to become a relationship lender. We match the location of the borrowers' and lenders' headquarters, provided by Dealscan, to the MaxMind World Cities Database to obtain information on the longitude and latitude. ${ }^{15}$ We are always able to identify the lender and the borrower location in MaxMind if the information on the location is provided by Dealscan. We treat observations as missing if the exact location of the lender or the borrower is not specified in Dealscan, which reduces the sample by 2,804 observations. We calculate the distance in miles between the borrower and the lead lender for each deal. ${ }^{16} \mathrm{We}$ follow Petersen and Rajan (2002) and address skewness in the distance measure by using $\ln (1+$ Distance $)$ in the regressions.

Table 5 reports the results of the IV-estimation using linear probability models in computing 2SLS estimates and correcting the standard errors for heteroskedasticity. ${ }^{17}$ Consistent

${ }^{15}$ The MaxMind database contains geographical information for about 3 million places in 234 countries and is publicly available at http://www.maxmind.com/app/worldcities.

${ }^{16}$ We use the same estimation formula as in Dass and Massa (2011). We assign the minimum distance to the deal in case of multiple lead lenders. See the Appendix for further details.

${ }^{17}$ Angrist and Pischke (2009) argue that this procedure yields consistent estimates. Several studies find that linear probability models produce results similar to partial effects from more precise models (see e.g., Angrist and Pischke (2009) and Katz et al. (2001)). However, our results are not sensitive to the question of whether we use linear probability models or bivariate probit models as advocated by Heckman (1978). 
with Bharath et al. (2011), we find that $\ln (1+$ Distance $)$ is significantly negatively correlated to all three proxies for lending relationship strength, confirming the validity of the inclusion restriction. The results of the second stage regressions confirm our previous results that PSD contracts are more likely to be used in the presence of bank lending relationships. In fact, if a firm borrows from the same lender a second time within 5 years, then the likelihood of including a performance-pricing provision in the second loan increases by $25 \%$ age points. ${ }^{18}$ This is statistically and economically highly significant. ${ }^{19}$

[Table 5 here]

Our results so far show that relationship lending is positively correlated with the use of accounting-based PSD. To establish whether this positive correlation is due to hold-up, we make use of the fact that the severity of the hold-up problem is likely to vary systematically across different types of borrowers. For example, more opaque borrowers have fewer financing alternatives, so that these borrowers are more subject to hold-up. Following Bharath et al. (2011), we use firm size as well as a dummy variable, which equals one if the borrower does

${ }^{18} \mathrm{As}$ in other studies that use instruments in relationship lending settings, the economic significance strongly increases in the IV-estimation. For example, Bharath et al. (2011) use IV regressions to examine the impact of lending relationships on loan spreads and find that the effect is more than 5 times stronger when using the distance between borrower and lender as an instrument for relationship lending. Berger et al. (2005) use IV regressions to examine the relationship between bank size and the exclusivity of bank-borrower relationships. Instrumenting bank size, they show a large increase in economic importance of bank size when compared to the OLS estimates.

${ }^{19}$ Ivashina and Kovner (2011) propose to use the variation in existing firms' lender concentration before a transaction to instrument for the selection of a given bank. Our results remain qualitatively similar when we use this instrument, i.e., the difference between the firm's highest and second-highest bank relationships before loan origination. 
not have a S\&P rating (and zero otherwise), as proxies for firm opacity. Another proxy for opacity is the number of analysts following the firm. Larger firms, rated firms, and firms with larger analyst coverage are more likely to have multiple financing alternatives, and are thus less "locked-in" in a bank lending relationship.

To test for the cross-sectional variation in the severity of the hold-up problem induced by lending relationships, we estimate the following model.

$$
\begin{aligned}
P S D_{i t} & =\alpha_{i}+\alpha_{t}+\alpha_{\text {Rat }}+\beta_{1} * \operatorname{Rel}(M)_{i t}+\beta_{2} * \text { BorrowerOpacity } i t \\
& +\beta_{3} * \operatorname{Rel}(M)_{i t} * \text { BorrowerOpacity } y_{i t}+\gamma * X_{i t}+\epsilon_{i t}
\end{aligned}
$$

BorrowerOpacity stands for the above-mentioned proxies for borrower opacity. We include interaction variables of relationship strength and BorrowerOpacity to test for the joint effect of these two variables. Due to the high correlation of the interaction variables, we include one variable at a time in the regressions. The results are reported in Table 6 .

[Table 6 here]

The coefficients of all interaction variables of borrower opacity are negative and statistically significant, which supports our hypothesis that opacity in the presence of a lending relationship increases the severity of hold-up, and hence the likelihood of using PSD. ${ }^{20}$

\footnotetext{
${ }^{20}$ Our results are robust to using the other two measures of relationship strength and to excluding all
} syndicated loans from the sample. These results are available from the authors upon request. 
A significant portion of our sample consists of syndicated loans. Asquith et al. (2005) argues that the use of PSD should be more likely in syndicated loans because their renegotiation costs are higher. As reported in Table 6, we find the use of performance-pricing provisions is indeed more likely in syndicated deals. According to Hypothesis 3, a relationship lead arranger should find it less beneficial to hold-up a borrower compared to a single lender because the gains from hold-up would have to be shared with the rest of the syndicate. As a result, the use of performance-pricing provisions should be less likely if the lead arranger is a relationship bank. The results reported in Table 6 confirm this hypothesis. The coefficient on $\operatorname{Rel}(\text { Dummy })^{*}$ Syndication is indeed negative and statistically highly significant.

A potential concern is that the syndication results are driven by the largest banks in the syndicated loan market. The market for syndication is dominated by three large banks (see Ross (2010)). Performance-sensitive debt should be less frequently used if the lending relationship is with one of these banks, because the top 3 banks are mostly transactionoriented, so that hold-up problems are less severe in relationships with these lenders. We find that our results still hold if we exclude all loans made by the top 3 banks from our sample. ${ }^{21}$

\footnotetext{
${ }^{21}$ These results are available from the authors upon request.
} 


\subsection{Performance-sensitive debt and covenants}

In this section, we investigate whether there is a substitution effect between the use of performance pricing grids and the tightness of financial covenants. In particular, Hypothesis 4 states that PSD contracts should have less tight covenants because the pricing grid prespecifies the consequences of small changes in a borrower's performance.

[Table 7 here]

Table 7 compares the covenant threshold levels used in PSD and non-PSD contracts. We find that PSD contracts have leverage and liquidity covenants with lower default thresholds than non-PSD contracts. For example, the median Debt-to-EBITDA covenant level for PSD contracts is 3.55 , and 4 for non-PSD contracts. This appears not to be supportive of Hypothesis 4. However, PSD and non-PSD are not unconditionally comparable, since borrower characteristics differ. A multivariate analysis is called for.

Furthermore, we now need to distinguish between interest-increasing and interest-decreasing PSD, because only interest-increasing PSD contracts should have an effect on covenant tightness. Interest-decreasing performance-pricing provisions matter only if a borrower's performance improves. To ensure that covenants and a loan's performance-pricing grid are based on the same variable, we restrict our analysis to covenants on the Debt-to-EBITDA ratio, which is the most frequently used performance measure in our sample. 
Following Dichev and Skinner (2002), we calculate the covenant tightness as the absolute difference between the Debt-to-EBITDA ratio at the initiation of the loan agreement and the Debt-to-EBITDA covenant threshold, normalized by the standard deviation of the borrower's Debt-to-EBITDA ratio over the previous 8 years. ${ }^{22}$ A lower ratio indicates a tighter covenant. We then estimate the following regression by OLS.

$$
\begin{aligned}
\text { Tightness }_{i t} & =\alpha_{i}+\alpha_{t}+\alpha_{\text {Rat }}+\beta_{1} * \text { IncreasingPSD } \\
& +\beta_{2} * \text { MixedPSD } D_{i t}+\beta_{3} * \text { DecreasingPSD } D_{i t}+\gamma * X_{i t}+\epsilon_{i t}
\end{aligned}
$$

The dependent variable, Tightness, is the tightness of the Debt-to-EBITDA covenant as defined above. $X$ represents loan and borrower characteristics. As before, we control for firm, time, loan purpose, loan type, and rating fixed effects. IncreasingPSD is a dummy variable, which equals one if the loan contains a pricing grid on Debt-to-EBITDA that only allows for interest rate increases. Decreasing $P S D$ is a dummy variable, which equals one if the loan contains a pricing grid on Debt-to-EBITDA that allows for interest rate decreases only, and MixedPSD is a dummy variable, which equals one if the loan contains a pricing grid on Debt-to-EBITDA that allows for both interest rate increases and decreases.

\section{[Table 8 here]}

\footnotetext{
${ }^{22}$ We lose observations because we require 8 years before the loan issue with non-missing observations on the Debt-to-EBITDA ratio to calculate the Debt-to-EBITDA standard deviation.
} 
As shown in Table 8, we find that interest-increasing PSD contracts have significantly less tight Debt-to-EBITDA covenants than straight debt. This is consistent with our hypothesis that performance-pricing affects covenant tightness: small changes in the credit risk of the borrower are regulated by performance-pricing provisions and not by tight covenants. Consistent with Freudenberg et al. (2014), we find that more highly levered borrowers have tighter Debt-to-EBITDA covenants. Borrowers with more growth opportunities have less tight covenants. ${ }^{23}$ A potential concern of estimating equation (5) by OLS is that the use of performance-pricing provisions is endogenous. We address this concern by estimating a Heckman-Selection Model. In the first stage we model the decision to use PSD as in Table 4. In the second stage we estimate equation (5) but also include the inverse Mills ratio from the first stage regression. The results are qualitatively similar to the OLS estimation, and available from the authors upon request.

\section{Robustness: hold-up vs. signaling}

Manso et al. (2010) show that PSD can be used as a signaling device to signal a firm's credit quality. Only borrowers who expect their credit ratings not to deteriorate are willing to enter into contracts that stipulate interest rate increases should the firm's credit rating decline. To test whether signaling explains the use of PSD, Manso et al. (2010) analyze the post-issue

${ }^{23}$ The accuracy and coverage of covenants reported in the Dealscan database has improved over time. However, our results are not sensitive to this issue and remain virtually unchanged if we restrict the sample to loans issued after 2000. These results are available upon request. 
credit rating development for firms that issue PSD vs. firms that issue straight debt. We use a similar methodology and further analyze the post-issue development of the firm's leverage ratio and its credit rating. We use the Debt-to-EBITDA ratio to measure leverage as this is the most common performance measure used in accounting-based PSD contracts. We distinguish between accounting-based and rating-based PSD in all specifications, because our results in Table 3 suggest that rating-based and accounting-based PSD are used for different purposes. In particular, we estimate the following regression.

$$
\begin{aligned}
\Delta \text { Performance }_{i t+1} & =\alpha_{i}+\alpha_{t}+\beta_{1} * P S D\left(\text { Rating }_{i t}+\beta_{2} * P S D\left(\text { Accounting }_{i t}\right.\right. \\
& +\gamma * X_{i t}+\epsilon_{i t}
\end{aligned}
$$

$\Delta$ Performance $_{i}$ is a dummy variable, which equals 1 if the borrower's credit rating improves in the first $k$ quarters after the loan issue and 0 otherwise $(k=4,8)$. In an alternative specification, $\Delta$ Performance ${ }_{i}$ is the difference between the firm's Debt-to-EBITDA ratio $k$ quarters after the loan issue and the firm's Debt-to-EBITDA ratio at the time of the loan issue $(k=4,8)$. $P S D$ (Rating) is a dummy variable, which equals one if the loan contains a pricing grid on the borrower's credit rating, while $P S D(\text { Accounting })_{i}$ is a dummy variable, which equals one if the loan contains a pricing grid on an accounting measure. The regression results are reported in Table 9 .

[Table 9 here] 
Consistent with the results reported by Manso et al. (2010), we find that firms are more likely to experience a rating improvement up to two years after issuing rating-based PSD relative to borrowers who issued regular debt. Furthermore, firms that issue ratingbased PSD see their leverage ratios decline by more than borrowers who issue straight debt. However, these results do not hold for accounting-based PSD. Neither credit ratings nor leverage ratios vary systematically after firms had issued accounting-based PSD. Accountingbased PSD contracts are thus unlikely to be motivated by signaling considerations. ${ }^{24}$

\section{Conclusion}

Von Thadden (1995) argues that pre-specifying loan contract terms can be an efficient way to mitigate hold-up problems in long-term lending relationships. An example is performancesensitive debt (PSD), which pre-specifies loan contract terms in events that would otherwise trigger debt renegotiations. In this paper, we test the hypothesis that PSD is used to reduce potential hold-up problems in bank lending relationships.

Consistent with this hypothesis, we find that accounting-based PSD contracts are $25 \%$ more likely to be used in relationship lending arrangements, after controlling for the endogeneity of the lending relationship. This is especially the case if the borrower is opaque and/or has fewer financing alternatives, both of which imply a greater potential for hold-up.

${ }^{24}$ Note that in these tests we aim at estimating correlations only, and do not make the claim that the use of PSD directly affects a firm's future performance. 
Syndicated deals are more likely to include performance-pricing provisions, which is consistent with the renegotiation cost argument by Asquith et al. (2005). However, relationship lenders as lead arrangers should find it less beneficial to hold-up a borrower as the gains from hold-up would have to be shared with the other syndicate members. This reduces the need for PSD. Indeed, we find that in syndicated relationship lending the use of PSD is less common.

We also find a substitution effect between the pricing grid and the tightness of covenants. The Debt-to-EBITDA covenants of interest rate increasing PSD contracts are less tight than the covenants of non-PSD contracts. This substitution effect is consistent with the recommendation by Von Thadden (1995) to pre-specify contract terms to mitigate hold-up.

In contrast to accounting-based PSD, we find no evidence that the use of rating-based PSD is motivated by hold-up considerations. In fact, several results are consistent with rating-based PSD used for signaling. Therefore we conclude that hold-up is likely an important determinant in the decision to issue accounting-based PSD, while signaling may motivate the decision to issue rating-based PSD. 


\section{References}

Agarwal, S. and R. Hauswald (2010). Distance and private information in lending. Review of Financial Studies 23, 2757-2788.

Angrist, J. D. and J.-S. Pischke (2009). Mostly Harmless Econometrics: An Empiricists Companion. Princeton University Press.

Asquith, P., A. Beatty, and J. Weber (2005). Performance pricing in bank debt contracts. Journal of Accounting and Economics 40, 101-128.

Berg, T., A. Saunders, and S. Steffen (2015). The total costs of corporate borrowing in the loan market: Don't ignore the fees. Journal of Finance, forthcoming.

Berger, A. N., N. H. Miller, M. A. Petersen, R. G. Rajan, and J. C. Stein (2005). Does function follow organizational form? Evidence from the lending practices of large and small banks. Journal of Financial Economics 72, 237-69.

Berger, A. N. and G. F. Udell (1995). Relationship lending and lines of credit in small firm finance. Journal of Business 68, 351-381.

Berlin, M. and L. J. Mester (1998). On the profitability and cost of relationship lending. Journal of Banking \& Finance 22, 873-897. 
Bhanot, K. and A. S. Mello (2006). Should corporate debt include a rating trigger? Journal of Financial Economics 79, 69-98.

Bharath, S., S. Dahiyab, A. Saunders, and A. Srinivasan (2007). So what do I get? The bank's view of lending relationships. Journal of Financial Economics 85, 368-419.

Bharath, S. T., S. Dahiya, A. Saunders, and A. Srinivasan (2011). Lending relationships and loan contract terms. Review of Financial Studies 24, 1142-1203.

Boot, A. W. A. (2000). Relationship banking: What do we know? Journal of Financial Intermediation 9, 7-25.

Boot, A. W. A. and A. V. Thakor (2000). Can relationship banking survive competition? Journal of Finance 55, 679-713.

Bradley, M. and M. R. Roberts (2003). The structure and pricing of corporate debt covenants. Unpublished Working Paper. University of Pennsylvania, Philadelphia..

Chava, S. and M. R. Roberts (2008). How does financing impact investment? The role of debt covenants. Journal of Finance 63, 2085 - 2121.

Coval, J. D. and T. J. Moskowitz (2001). The geography of investment: Informed trading and asset prices. Journal of Political Economy 109, 811-841.

Dass, N. and M. Massa (2011). The impact of a strong bank-firm relationship on the borrowing firm. Review of Financial Studies 24, 1204-1260. 
Degryse, H. and P. V. Cayseele (2000). Relationship lending within a bank-based system: Evidence from european small business data. Journal of Financial Intermediation 9, 90109.

Degryse, H. and S. Ongena (2005). Distance, lending relationships, and competition. Journal of Finance 60, 231-266.

Demiroglu, C. and C. M. James (2010). The information content of bank loan covenants. Review of Financial Studies 23, 3700-3737.

Dichev, I. D. and D. J. Skinner (2002). Large-sample evidence on the debt covenant hypothesis. Journal of Accounting Research 40, 1091-1123.

Elsas, R. and J. P. Krahnen (1998). Is relationship lending special? Evidence from credit-file data in germany. Journal of Banking \& Finance 22, 1283-1316.

Farinha, L. A. and J. A. C. Santos (2002). Switching from single to multiple bank lending relationships: Determinants and implications. Journal of Financial Intermediation 11, $124-151$.

Freudenberg, F., B. Imbierowicz, A. Saunders, and S. Steffen (2014). Covenant violations and dynamic loan contracting. Unpublished Working Paper. New York University, New York. 
Hale, G. and J. A. C. Santos (2009). Do banks price their informational monopoly? Journal of Financial Economics 93, 185-206.

Heckman, J. J. (1978). Dummy endogenous variables in a simultaneous equation system. Econometria 46, 931-959.

Houston, J. F. and C. M. James (1996). Bank information monopolies and the mix of private and public debt claims. Journal of Finance 51, 1863-1899.

Ivashina, V. and A. Kovner (2011). The private equity advantage: Leveraged buyout firms and relationship banking. Review of Financial Studies 24, 2462-2498.

Katz, L. F., J. R. Kling, and J. B. Liebman (2001). Moving to opportunity in boston: Early results of a randomized mobility experiment. Quarterly Journal of Economics 116, $607-654$.

Koziol, C. and J. Lawrenz (2010). Optimal design of rating-trigger step-up bonds: Agency conflicts versus asymmetric information. Journal of Corporate Finance 16, 182-204.

Manso, G., B. Strulovici, and A. Tchistyi (2010). Performance-sensitive debt. Review of Financial Studies 23, 1819-1854.

Mattes, J. A., S. Steffen, and M. Wahrenburg (2012). Do information rents in loan spreads persist over the business cycles? Journal of Financial Services Research, 1-21. 
Menkhoff, L., D. Neuberger, and C. Suwanaporn (2006). Collateral-based lending in emerging markets: Evidence from Thailand. Journal of Banking \& Finance 30, 1-21.

Murfin, J. (2012). The supply-side determinants of loan contract strictness. Journal of Finance 67, 1565-1601.

Nikolaev, V. V. (2013). Scope for renegotiation and debt contract design. Unpublished Working Paper. University of Chicago, Chicago..

Norden, L. and M. Weber (2010). Credit line usage, checking account activity, and default risk of bank borrowers. Review of Financial Studies 23, 3665-3699.

Ongena, S. and D. C. Smith (2000). What determines the number of bank relationships? Cross-country evidence. Journal of Financial Intermediation 9, 26-56.

Petersen, M. and R. Rajan (1995). The effect of credit market competition on lending relationships. Journal of Quarterly Economics 110, 406-443.

Petersen, M. A. and R. G. Rajan (1994). The benefits of lending relationships: Evidence from small business data. Journal of Finance 49, 3-37.

Petersen, M. A. and R. G. Rajan (2002). Does distance still matter? The information revolution in small business lending. Journal of Finance 57, 2533-2570.

Rajan, R. G. (1992). Insiders and outsiders: The choice between informed and arm's-length debt. Journal of Finance 47, 1367-1400. 
Ross, D. G. (2010). The "dominant bank effect:" How high lender reputation affects the information content and terms of bank loans. Review of Financial Studies 23, 2730-2756.

Santos, J. A. C. and A. Winton (2008). Bank loans, bonds, and information monopolies across the business cycle. Journal of Finance 63, 1315-1359.

Saunders, A. and S. Steffen (2011). The costs of being private: Evidence from the loan market. Review of Financial Studies 24, 4091-4122.

Schenone, C. (2010). Lending relationships and information rents: Do banks exploit their information advantages? Review of Financial Studies 23, 1149-1199.

Schmidt, K. M. (2006). The economics of covenants as a means of efficient creditor protection. European Business Organization Law Review 7, 89-94.

Sharpe, S. A. (1990). Asymmetric information, bank lending and implicit contracts: A stylized model ofcustomer relationships. Journal of Finance 45, 1069-1087.

Sufi, A. (2007). Information asymmetry and financing arrangements: Evidence from syndicated loans. Journal of Finance 62, 629-668.

Tchistyi, A., D. Yermack, and H. Yun (2011). Negative hedging: Performance-sensitive debt and CEOs' equity incentives. Journal of Financial and Quantitative Analysis 46, 657-686.

Von Thadden, E.-L. (1995). Long-term contracts, short-term investment and monitoring. Review of Economic Studies 62, 557-575. 
Figure 1: Covenant Thresholds of PSD and non-PSD Contracts

This figure shows the Debt-to-EBITDA covenant threshold of a hypothetical regular debt contract and compares it with the covenant threshold of debt with a performance pricing provision. The covenant of regular debt is tighter than the covenant of PSD.

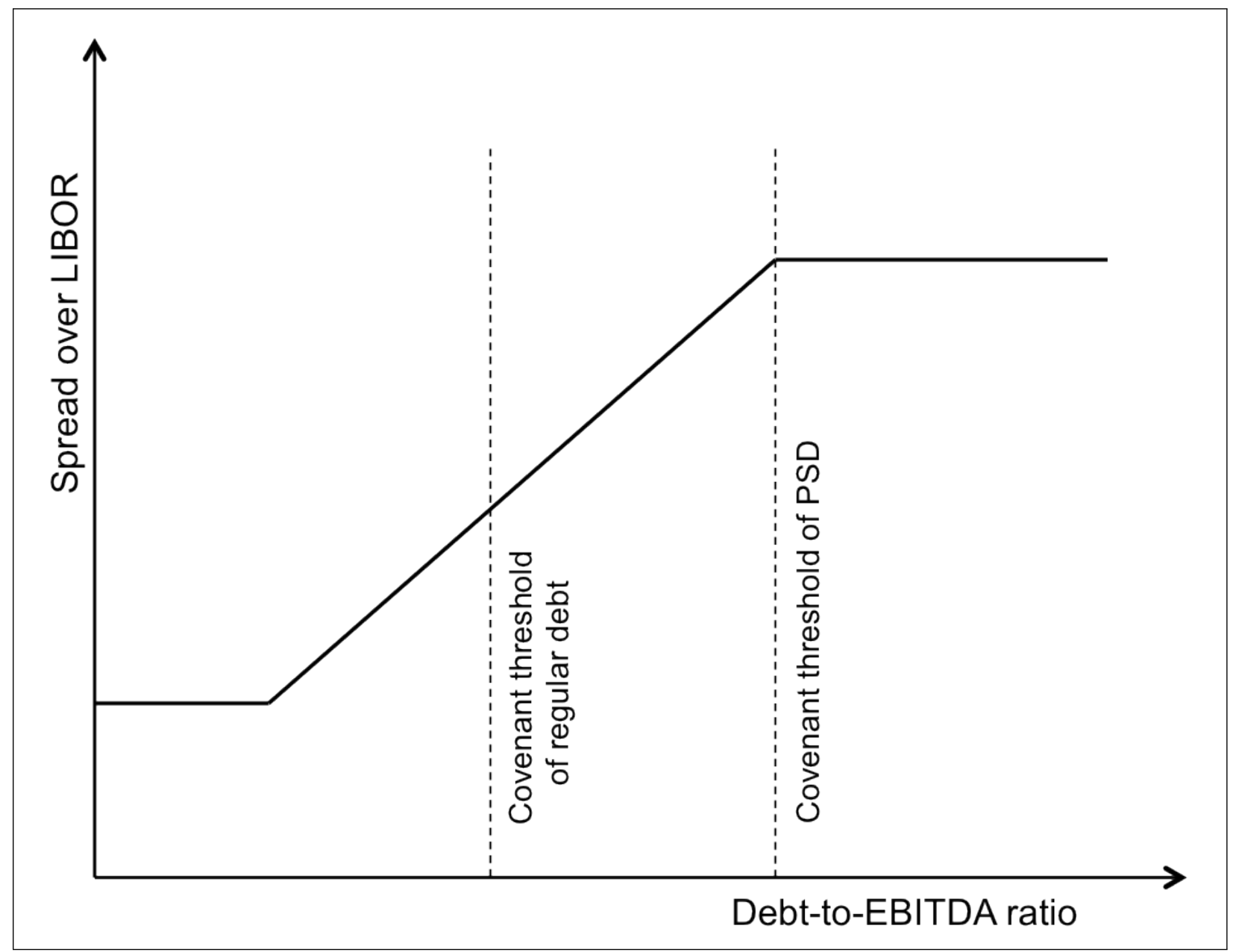


Figure 2: Accounting-Based PSD

This figure shows the pricing grid of a loan issued by Urban Outfitters Inc in 2007. The spread is contingent on the issuer's Debt-to-EBITDA ratio. The Debt-to-EBITDA ratio at the time of loan issue was 4 . The initial spread paid was LIBOR $+150 \mathrm{bp}$.

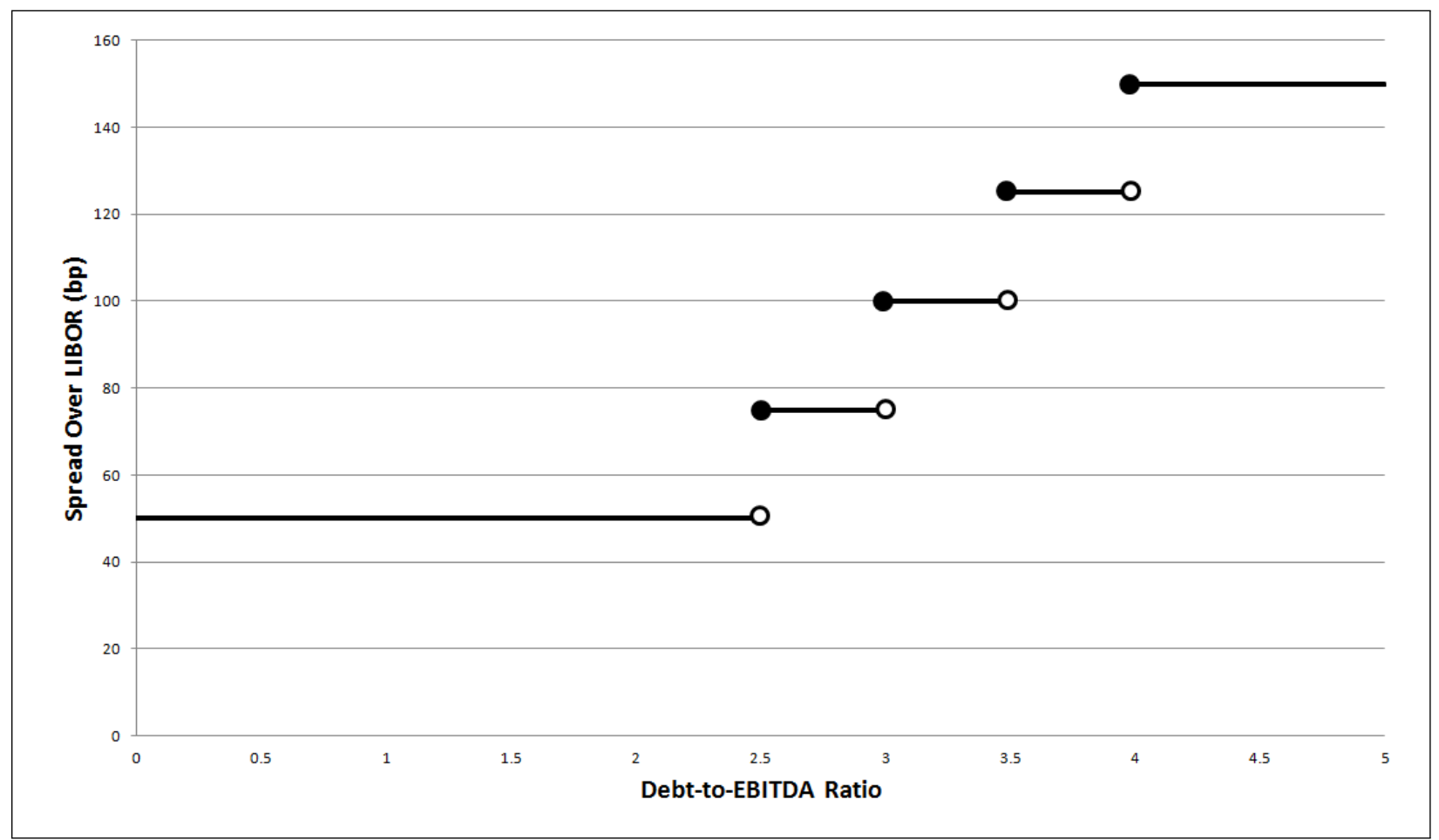


Figure 3: Rating-Based PSD

This figure shows the pricing grid of a loan issued by IBM in March 2004. The loan spread is a function of IBM's S\&P senior debt rating. IBM's senior debt rating at the time of loan issue was $\mathrm{A}+$. The initial spread paid was LIBOR $+12 \mathrm{bp}$.

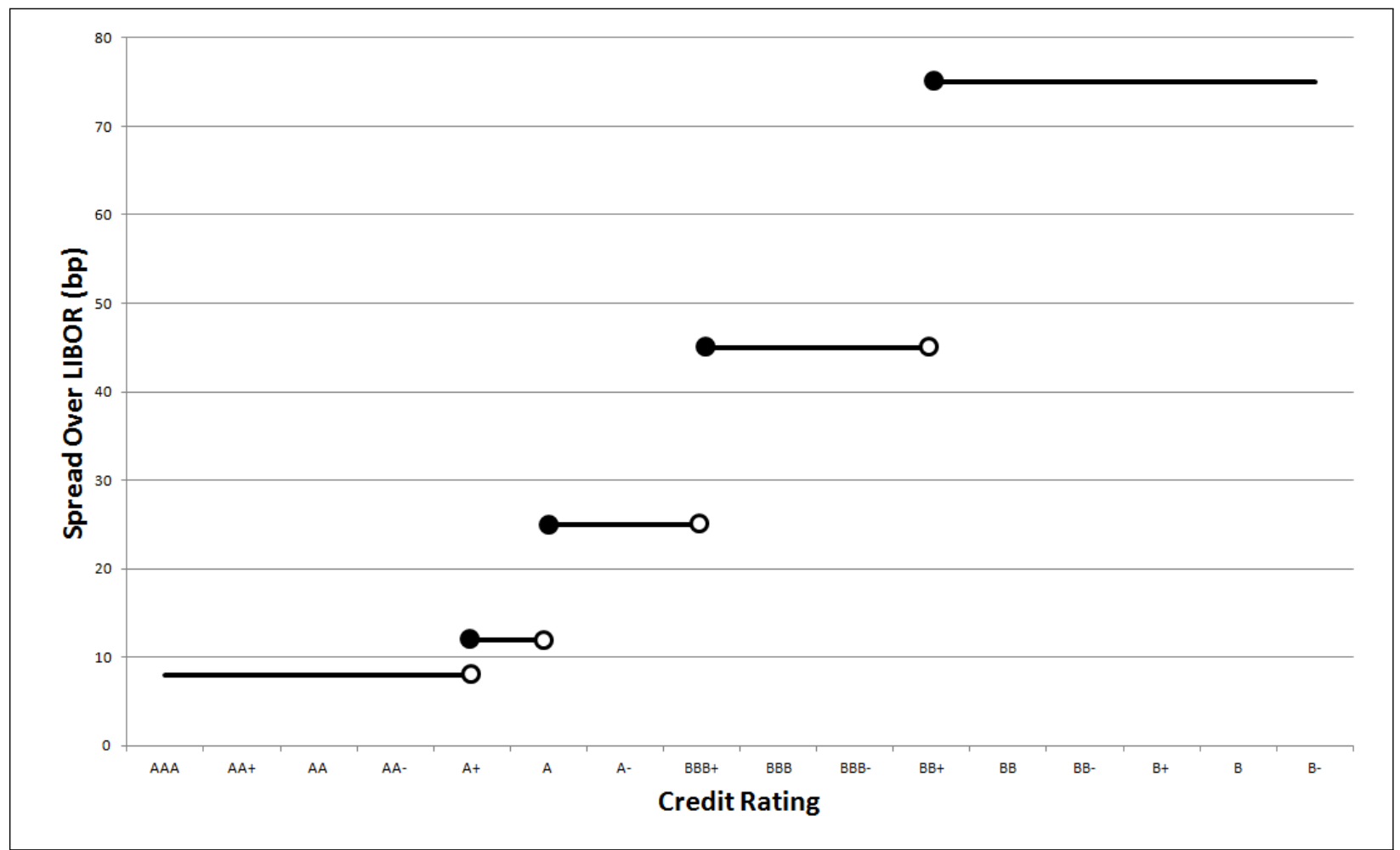




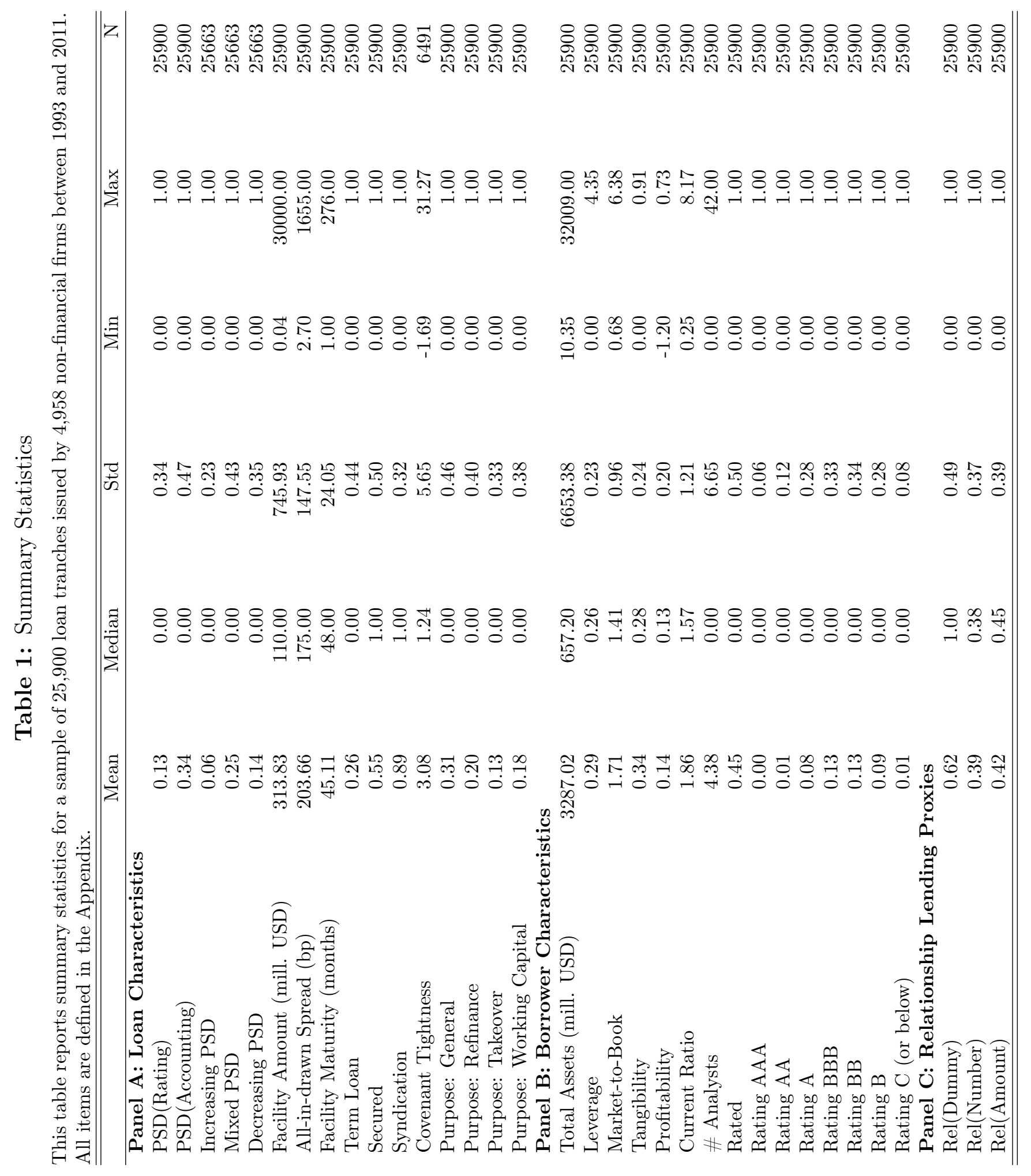




\section{Table 2: PSD Contract Types}

This table reports the types and frequencies of performance-pricing provisions used in our sample of PSD contracts issued between 1993 and 2011.

\begin{tabular}{lcr}
\hline \hline & Frequency & Observations \\
\hline Panel A: Accounting-Based PSD & & \\
Debt-to-EBITDA & 0.48 & 5859 \\
User Condition & 0.06 & 727 \\
Multiple & 0.04 & 518 \\
Leverage & 0.04 & 461 \\
Senior Debt to Cash Flow & 0.03 & 384 \\
Fixed Charge Coverage & 0.02 & 267 \\
Other Accounting Measures & 0.02 & 242 \\
Outstandings & 0.02 & 219 \\
Debt-to-Tangible Net Worth & 0.01 & 178 \\
Interest Coverage & 0.01 & 148 \\
Panel B: Rating-Based PSD & & \\
Senior Debt Rating & 0.26 & 3094 \\
Other Credit Rating & 0.00 & 21 \\
\hline Total & 1.00 & 12134 \\
\hline \hline
\end{tabular}




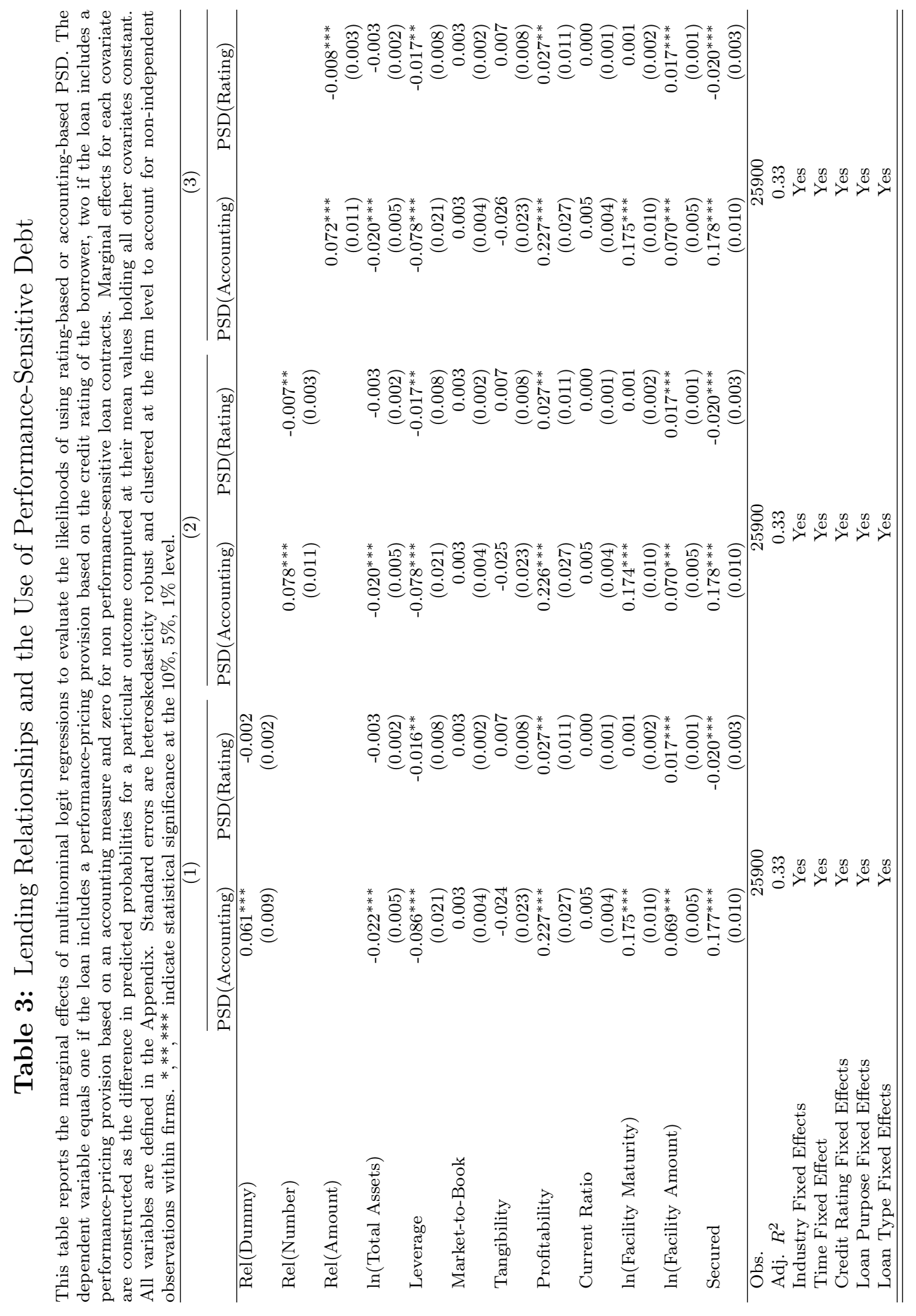




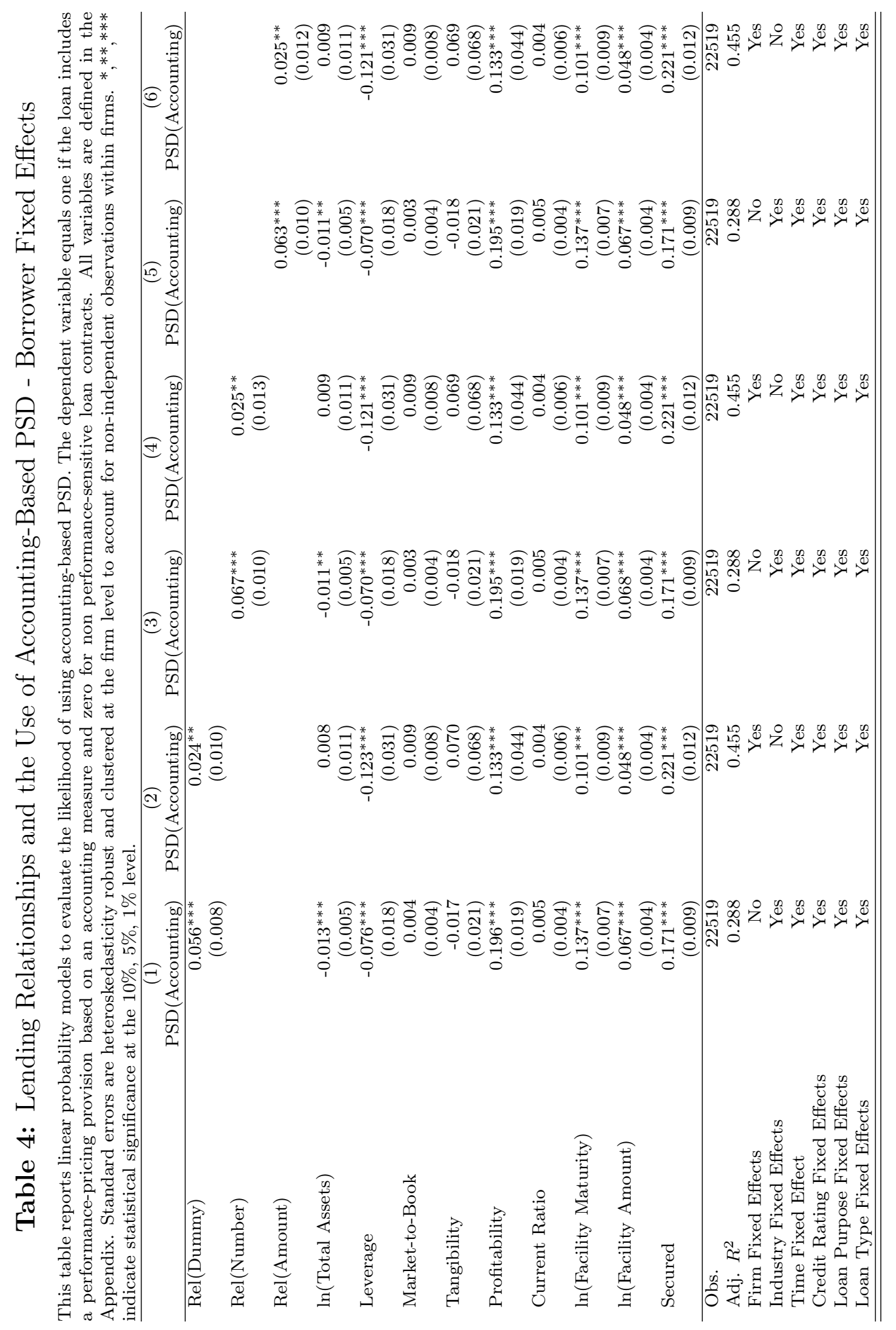




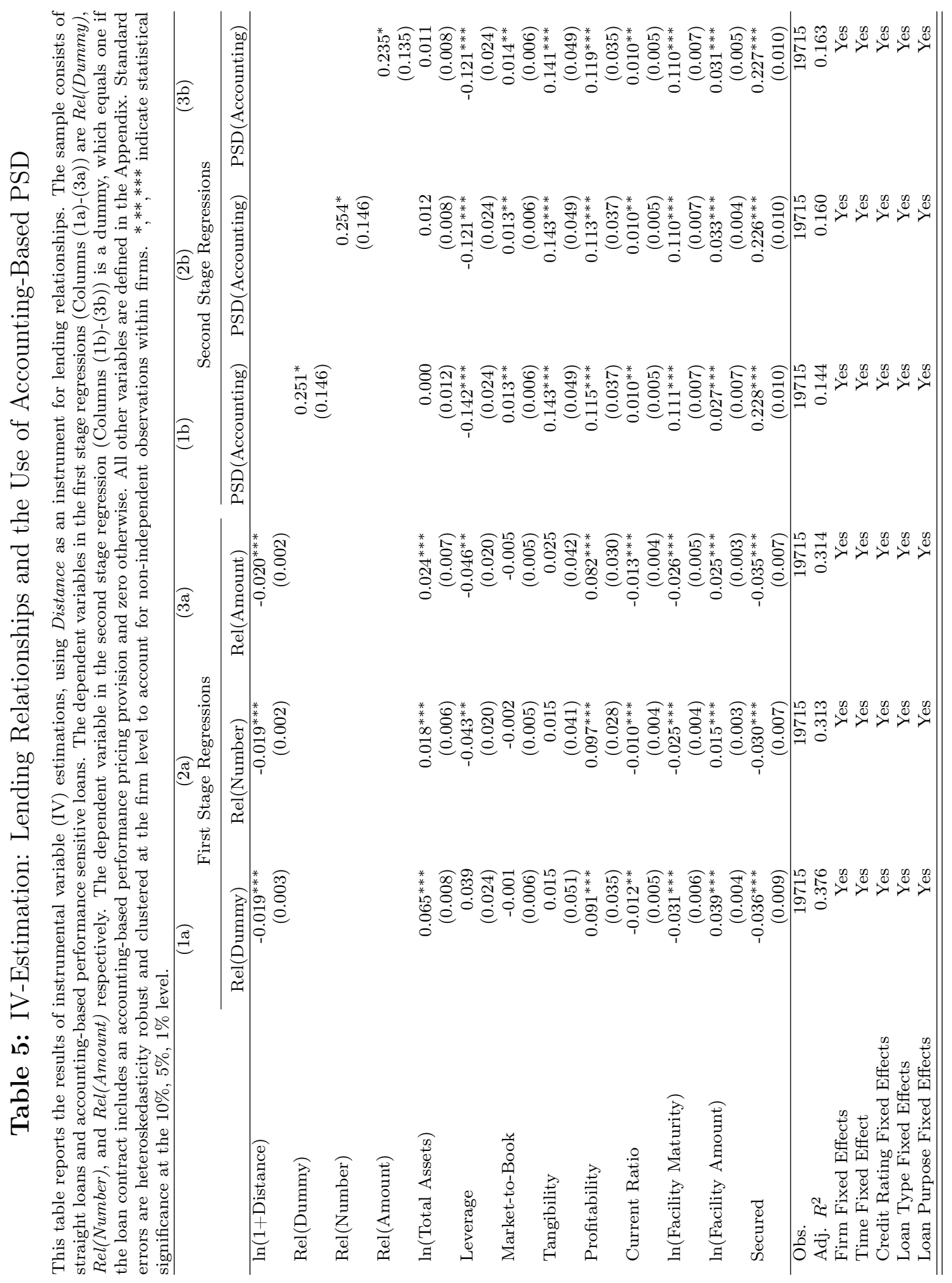




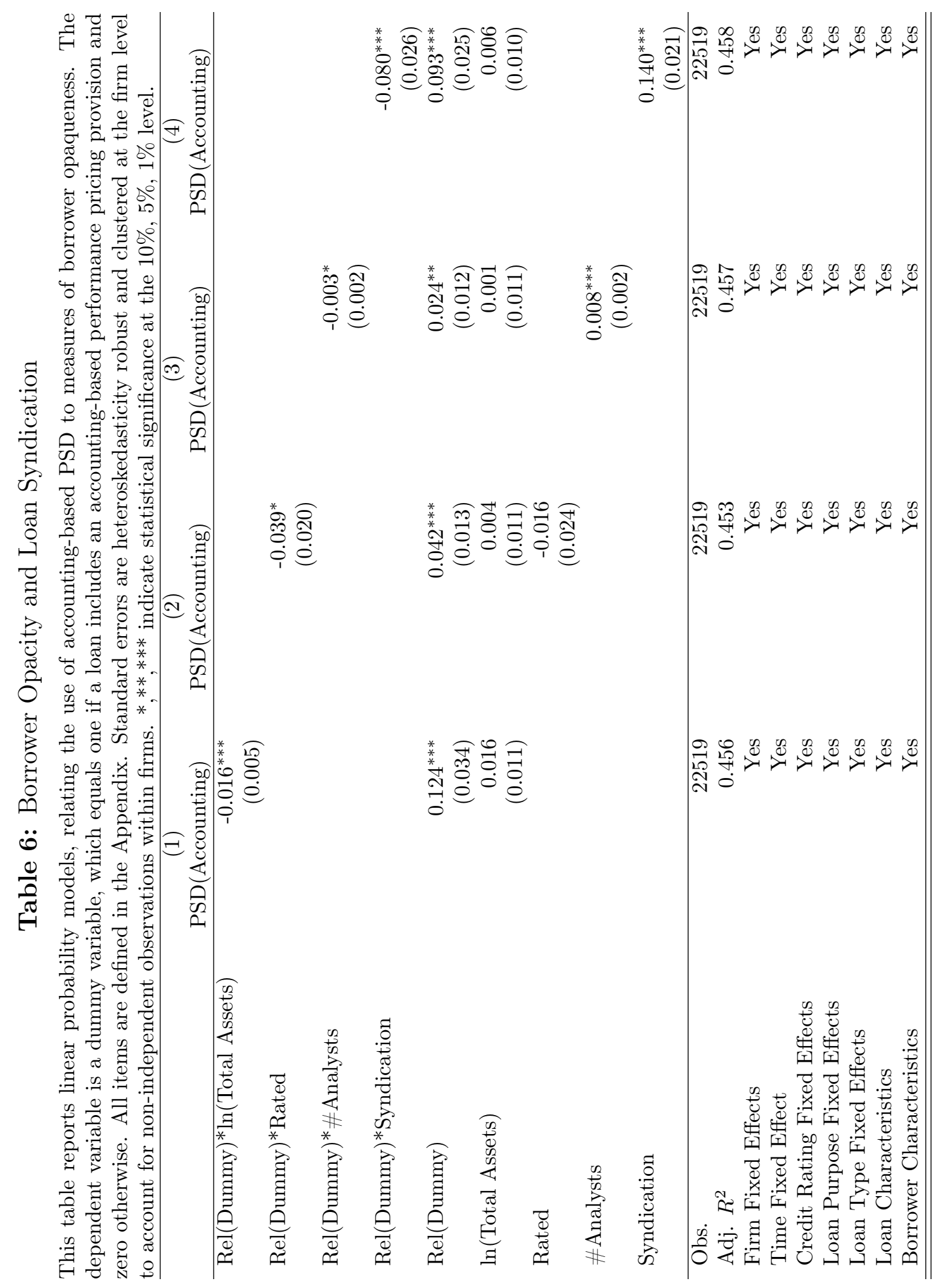




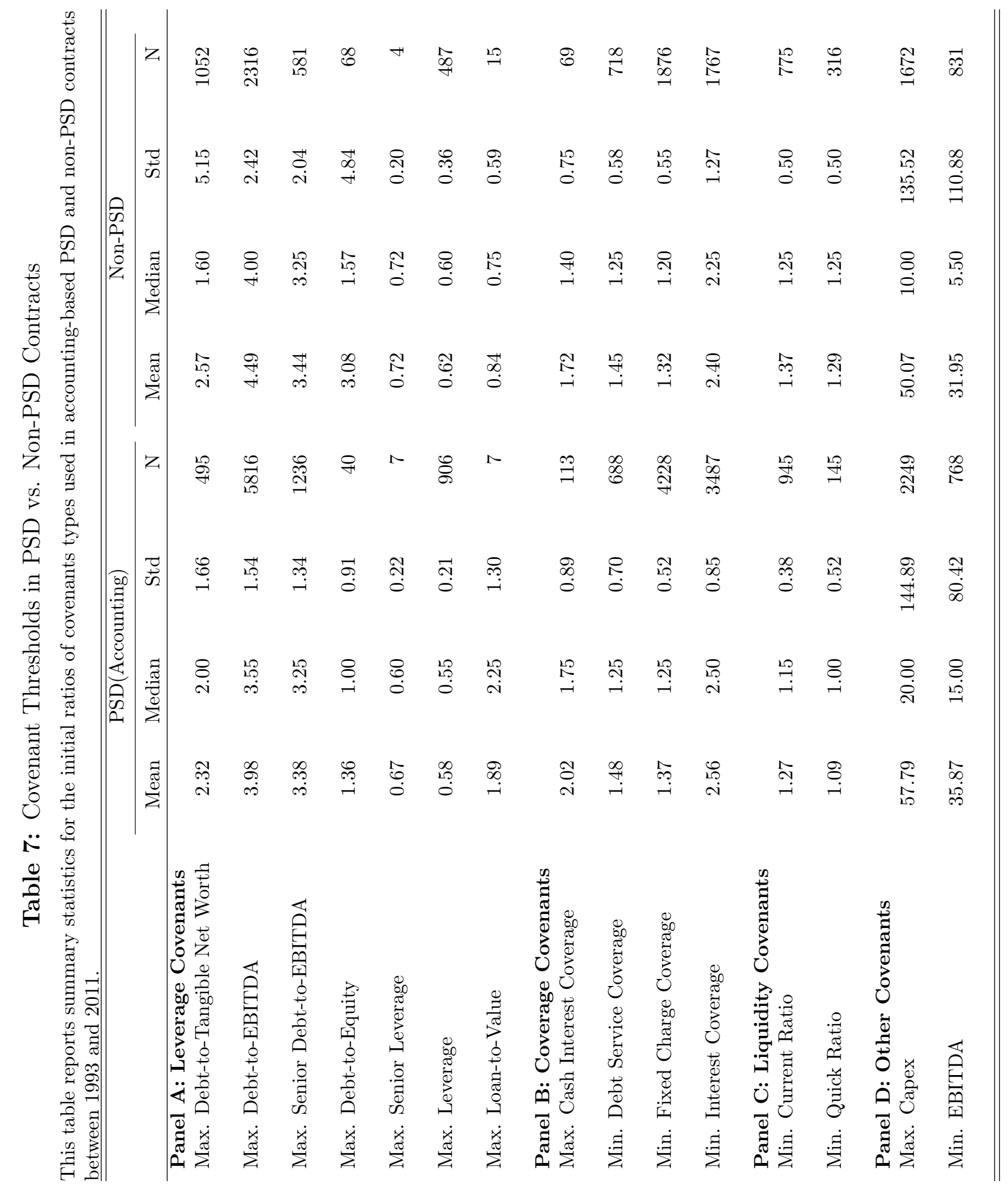




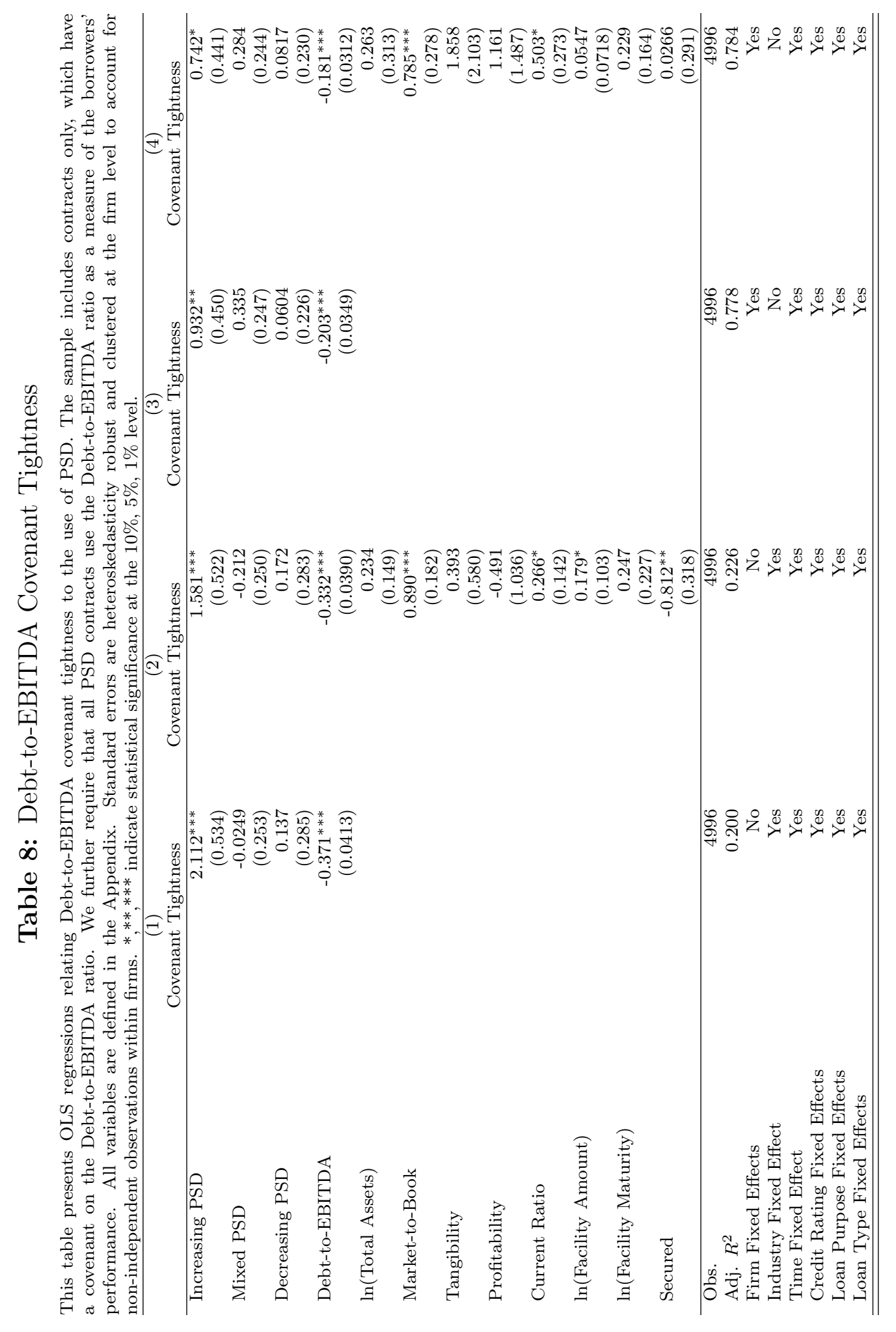




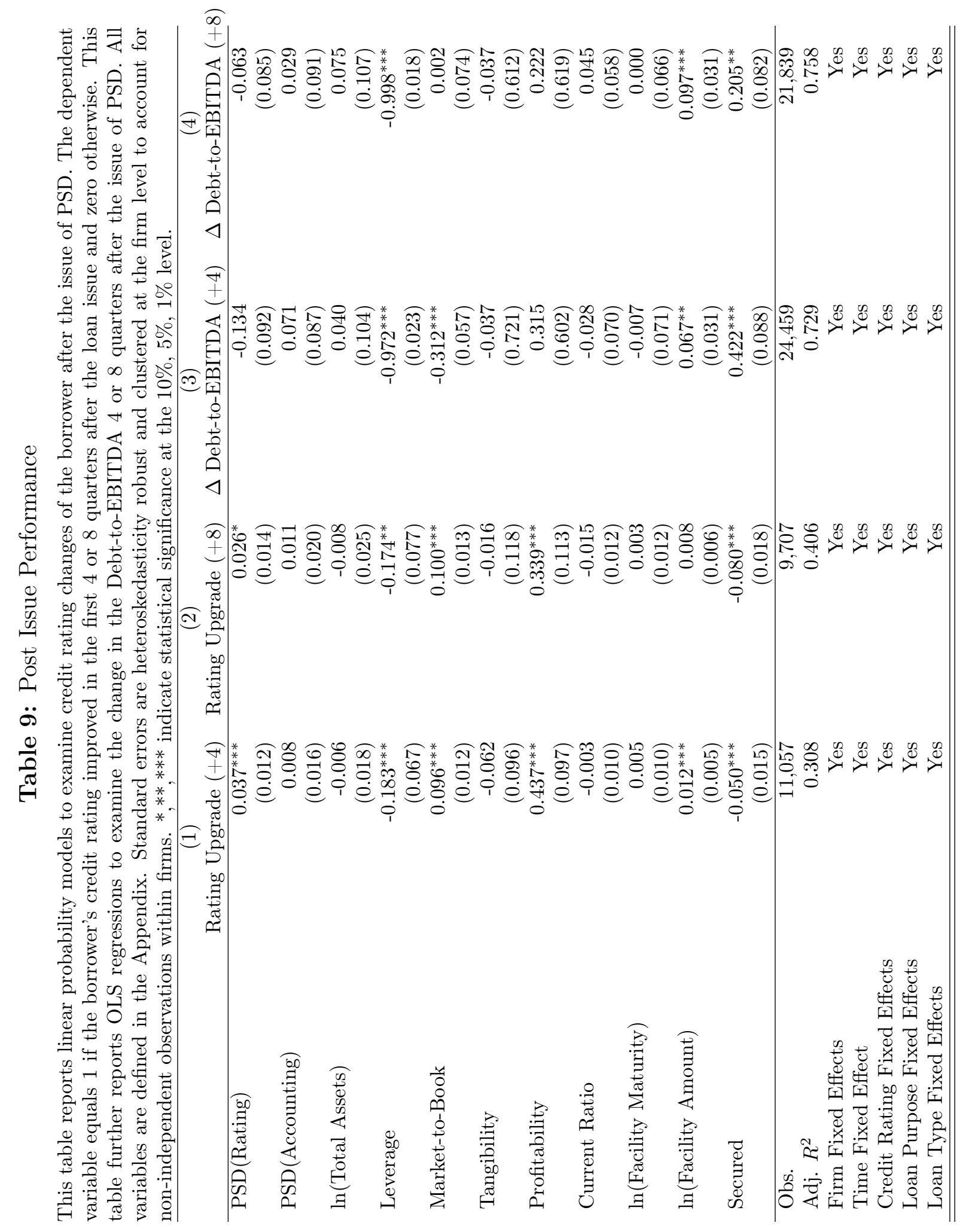




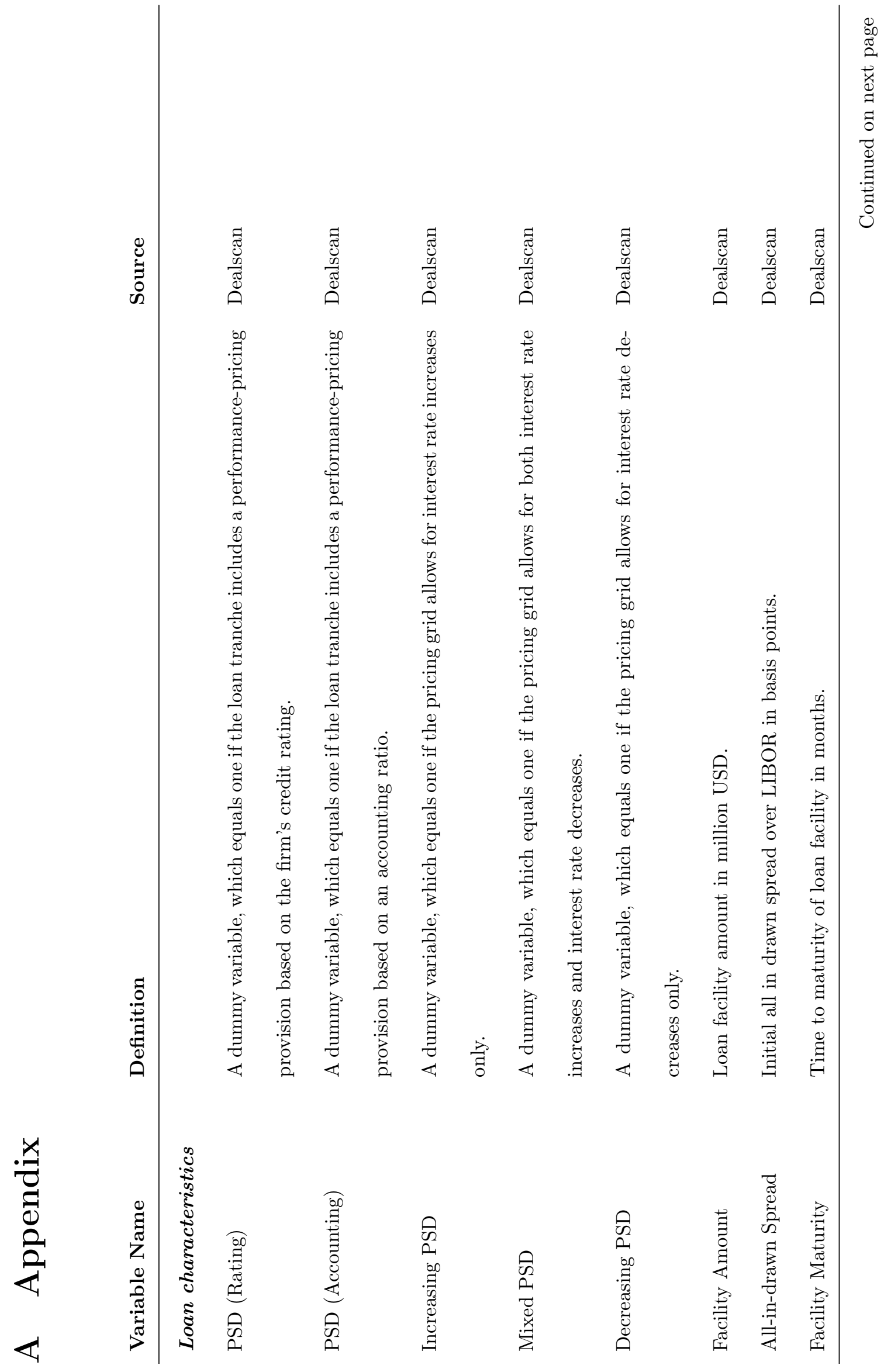




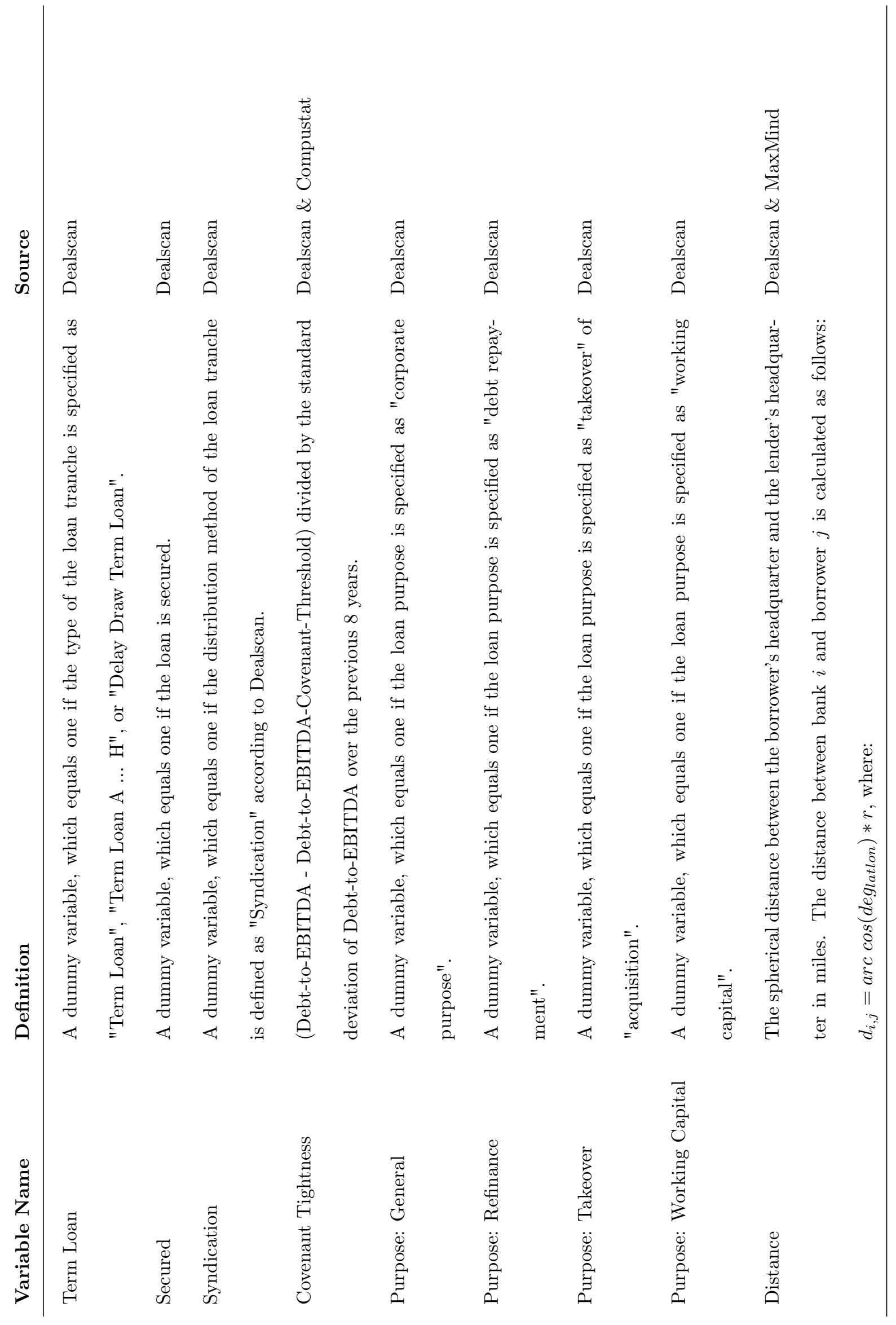

0
0
0
0
0
0
0
0
0
0
0
0
.70
0
0 


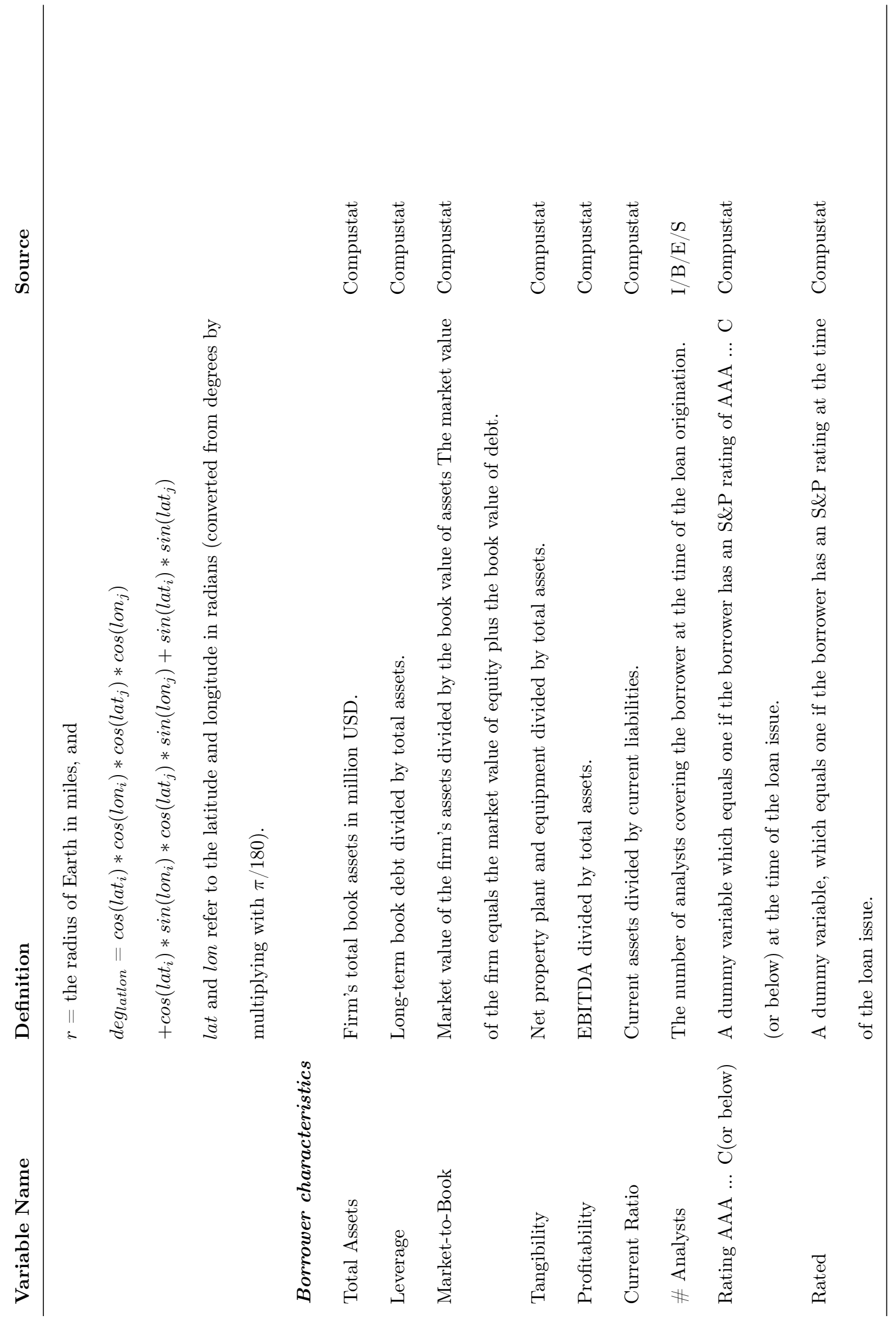

0
0
0
0
0
0
0
0
0
0
0
0
.0
00
0 


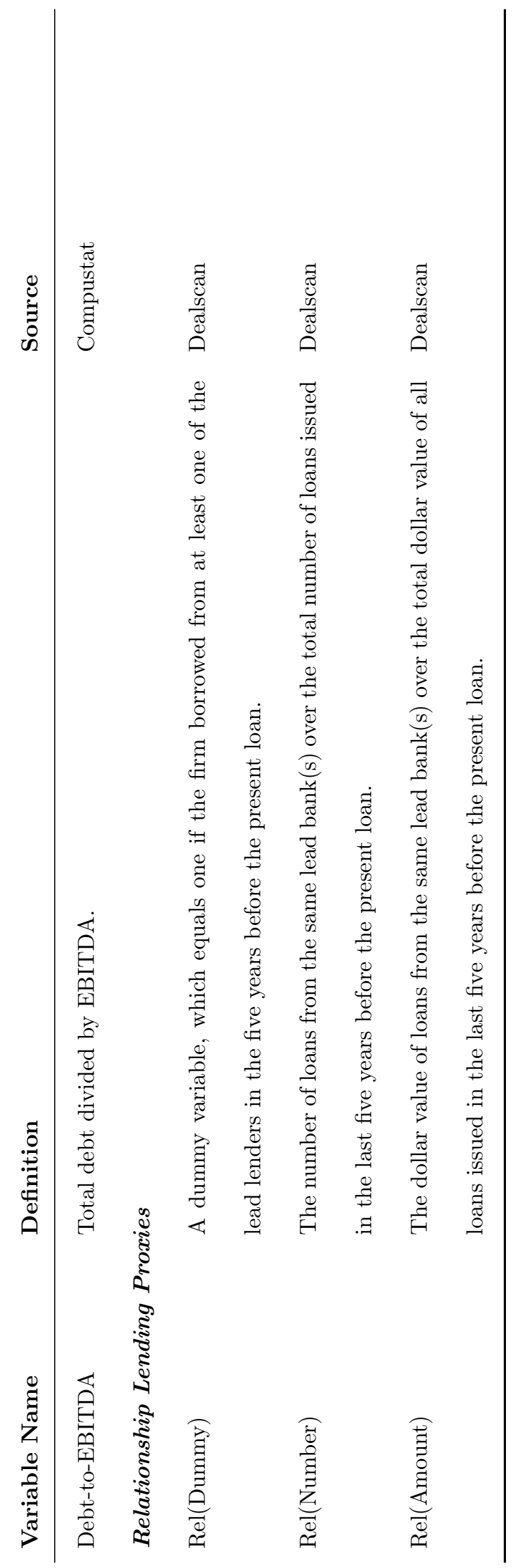

